\title{
KLASZTOR AUGUSTIANÓW W KSIĄżU WIELKIM
}

Autor poniższego opracowania — nasz Ojciec — interesował się od młodych lat historią swej rodzinnej miejscowości i jej okolicy. Lata studiów w Uniwersytecie Jagiellońskim (1935 - 1939) ugruntowały te zainteresowania i zainicjowały cykl monografii na temat zabytków i historii Książa Wielkiego. Toteż zamiarem jego było opracowanie całoksztaltu dziejów Książa Wielkiego, od czasów osadnictwa prehistorycznego do epoki nam współczesnej. Ciekawość poznawcza i dociekliwość w odtwarzaniu dziejów stworzyły u Autora świadomość ciąglej potrzeby prowadzenia prac badawczych w archiwach i bibliotekach, też na terenie własnej miejscowości.

Pracy tej jednak mógł się poświęcić tylko dorywczo, gdyż w równej mierze pochłaniała go praca zawodowa. Był organizatorem i wykładowcą na kompletach tajnego nauczania poziomu szkoły średniej w Książu Wielkim w czasach drugiej wojny światowej. Po wojnie był założycielem i dyrektorem Liceum Ogólnokształcącego w Książu Wielkim, a następnie wieloletnim nauczycielem języka polskiego i historii w Liceum Ogólnokształcącym w Miechowie. Będąc dyrektorem Liceum Ogólnokształcącego w Książu Wielkim, podjął się dzieła odbudowy zamku „Na Mirowie”. Historia tego zamku jest tematem jednej z jego monografii (zob. niżej wykaz źródel).

Postawione sobie przezeń zadanie przerastało jednak możliwości jednego człowieka, a nieubłagany czas przemijania pozwolił zakończyć tylko niektóre rozdziały z dziejów Książa. Takim rozdziałem jest $\mathrm{m}$. in. niniejsze opracowanie, przedstawiające dzieje ksiąskiego klasztoru Augustianów od początku do r. 1894, w którym to roku zmarł ostatni przedstawiciel zakonu.

Badania dziejów klasztoru poaugustiańskiego w Książu Wielkim rozpoczął Ojciec podczas studiów uniwersyteckich. Ich pierwszym krokiem była penetracja rękopisów w Archiwum oo. Augustianów przy kościele św. Katarzyny w Krakowie. Jednocześnie, w okresie przedwojennym, każdorazowy pobyt w Książu Wielkim wykorzystywał na przepisywanie kroniki parafialnej, dokonując przy tym kopiowania z niej planów. W latach okupacji niemieckiej Ojciec mieszkał w Książu Wielkim i w tym czasie zapoznał się z miejscowymi archiwaliami parafialnymi i poklasztornymi. W tym czasie wykonal również liczne zdjęcia fotograficzne, z których wiele nie dałoby się dzisiaj powtórzyć, gdyż sfotografowane zabytki już nie istnieją.

Po śmierci naszego Ojca w r. 1986, z materiałów zebranych i opracowanych przez niego przygotowaliśmy do druku niniejszą rozprawę. Nie jest ona jednak zaopatrzona w przypisy, gdyż Ojciec nie zdołal ich już wprowadzić. Brak tego koniecznego aparatu naukowego kompensuje w jakimś stopniu wykaz źródel archiwalnych i drukowanych zamieszczony na końcu artykułu. Przygotowując maszynopis, staraliśmy się zachować jego treść w niezmienionej postaci, wprowadzając jedynie drobne poprawki i uzupełnienia.

Książ Wielki, marzec 1988 r.

Stawomira z Madejskich Tkaczykowa Lech Madejski 


\section{FUNDACJA KLASZTORU}

Gdy od strony południowej patrzymy na wielkoksiąskie wzgórze, wówczas naszą uwagę mogą przyciągnąć jasne mury zabytkowego kościoła pod wezwaniem św. Ducha i poklasztornego budynku. Ten zakątek Książa Wielkiego wygląda szczególnie malowniczo na tle bogatej zieleni drzew i krzewów oraz błękitu nieba. Znajdujące się w nim zabytkị mogą nas również zainteresować swoim długim żywotem, swoją sześciowiekową przeszłością. Gdy ją poznajemy, wówczas pogrążamy się w zadumie nad tym, że chociaż te zabytki stawały się ofiarą różnych kataklizmów, to mimo wszystko jakimś szczęśliwym trafem podnosiły się zawsze z gruzów i popiołów.

Kolebką augustianów - pustelników, których osiedlono w Polsce a między innymi w Książu Wielkim, były Włochy. Ich zakon (Ordo Fratrum Eremitarum Sancti Augustini) został powołany do życia w 1256 r. przez papieża Aleksandra IV. Wkrótce potem klasztory tego zakonu zaczęły się pojawiać na Pomorzu i Sląsku. Szczególnie byli augustianie popularni w Polsce w XIV stuleciu. Około r. 1342 sprowadzil ich z Czech do Krakowa król Kazimierz Wielki i wybudował im na Kazimierzu (wówczas odrębne miasto) wspaniały kościól.

Pustelników, czyli eremitów (heremitów) św. Augustyna, sprowadził do Książa Wielkiego, swego miasta, Jan z Melsztyna, przedstawiciel możnego rodu Leliwitów. Przez wiele lat był on doradcą Kazimierza Wielkiego, a potem jego następcy. Poza tym doczekał się na dworze ostatniego Piasta dużego awansu, gdy otrzymał kasztelanię krakowską. Do tej zaś fundacji miejscowego klasztoru zachęcał prawdopodobnie dziedzica miasta przykład króla, któremu wiele placówek tego zakonu zawdzięczało swój początek.

Jan z Melsztyna przez małżeństwo z Offką (Zofią) z Książa, wywodzącą się, co jest bardzo prawdopodobne, z rodu Toporczyków dostał część miasta w swoje ręce. W r. 1372 kupił dalsze części dóbr ksiąskich od braci małżonki Jana i Adama, łącznie z prawem patronatu parafialnego kościoła. Gdy to osiągnął, mógł już wtedy przystąpić do wyznaczania parceli dla augustianów. Wówczas wybrał dla nich południowo-wschodnią część ówczesnego miasta, która znajdowała się w trójkącie jego obronnych murów (drewniano-ziemnych). Następnie w ciągu kilku lat kasztelan krakowski wybudował kościół na obranym miejscu. Dokonał tego dzieła jeszcze za swego życia. Zmarł pod koniec $1380 \mathrm{r}$. lub z początkiem następnego.

Po śmierci kasztelana najstarszy jego syn Spytek (Spytko) otrzymał po nim część bogatej spuścizny, łącznie z Książem Wielkim. Dokumentem z 20 grudnia $1381 \mathrm{r}$. postanowil on uporządkować swoje stosunki prawne $\mathrm{z}$ augustianami. Zatwierdził w nim nadania ojcowskie i jednocześnie, zgodnie z wolą swej matki Zofii, przekazal im plac pod budowę obiektu mieszkalnego, czyli klasztoru. Pierwszy budynek mieszkalny, czyli klasztor, wzniesiony przez Spytka z Melsztyna dla augustianów sprowadzonych do Książa Wielkiego, był drew- 
niany i o takim później wspominają wizytacje biskupie. Ten akt był nie tylko potwierdzeniem i wzmocnieniem fundacji, dokonanej przez kasztelana, lecz jednocześnie jej powiększeniem nowymi darowiznami. Do naszych czasów nie dochował się akt fundacyjny w oryginale, ale tylko kopia, którą w formie oblaty wniesiono do ksiąskich ksiąg ziemskich. W r. 1599 uczynił to przeor miejscowego konwentu Maciej Karski.

Nowy dziedzic miasta, piastujący już urząd wojewody krakowskiego, przeznaczył znowu na utrzymanie wielkoksiąskich zakonników 1/3 dochodu z młyna, zwanego od dawna „wójtowskim”, oraz jedną jatkę rzeźniczą w mieście. Poza tym zapisał klasztorowi folwark z ogrodem, polami i łąką „wójtowską”. W dokumencie oznaczył też Spytko granice podarowanych gruntów, które na szerokość ciągnęły się od pól Mianocic po miedze wsi Częstoszowice, a miarą ich długości były znowu drogi z Mianocic do Częstoszowic i z Rzędowic do Skalbmierza. Przy tej samej okazji nadał on jeszcze tutejszemu klasztorowi immunitet, który zwalnial go od wszelkich świadczeń na rzecz miasta Książa Wielkiego. Jednocześnie wyłączał on augustianów od obowiązku dawania stróży i składania wszelkich opłat do kasy miejskiej.

O dalszym przyroście gruntów klasztornych, które dostały się miejscowym augustianom z rąk Melsztyńskich, informuje nasz historyk Jan Długosz. Według jego zapisu, po śmierci Spytka w bitwie z Tatarami nad rzeką Worsklą w r. 1399 owdowiała po nim Elżbieta, niegdyś dwórka królowej Jadwigi, przekazała wielkoksiąskim pustelnikom św. Augustyna w formie jałmużny nowe grunta orne z łąkami. Znajdowały się one za ogrodami miejskimi i nosily nazwę „gruntów dolnych”. Nie wspomniał jednak Długosz o innej darowiźnie, która z rąk tej samej Elżbiety dostała się konwentowi 28 lipca 1403 r. Chodziło tutaj o kawał gruntu koło ogrodów miejskich, między gościńçem żarnowieckim a drogą do Konaszówki. Innego rodzaju jałmużnę, zapisaną 1 lipca 1437 r. w krakowskich księgach ziemskich, ofiarował tutejszemu konwentowi dziedzic pobliskiego Kozłowa - Jarosław. Zezwolił on eremitom z Książa ścinać drzewo w lesie, zwanym Bryzdzyn, i to w takiej ilości, jaka będzie im potrzebna dla własnego użytku.

$\mathrm{Na}$ tych darowiznach $\mathrm{z}$ pierwszych lat $\mathrm{XV}$ wieku, które były aktem dobrej woli wdowy po wojewodzie Spytku, urywają się na długi okres większe ofiary dla miejscowego klasztoru. Nastąpiło to wtedy, gdy Elżbieta ok. 1407 r. zawarła związek małżeński z Janem, księciem na Ziębicy.

Ciężkie chwile musiały nadejść dla miejscowego konwentu, gdy w Polsce pojawił się husytyzm za panowania Władysława Jagiełły. Jego wpływom uległ wtedy Spytek z Melsztyna, syn bohatera znad Worskli. Był on stryjem i, przez dłuższy okres, prawnym opiekunem nieletniej dziedziczki Książa Wielkiego, zwanej popularnie Jadwigą Ksiąską. Tenże Spytek na czele husytów w bitwie z konfederacją katolicką zginął pod Grotnikami w r. 1439.

Sytuacja eremitów w Książu nie mogła się poprawić w latach następnych, 
gdy mężem Jadwigi Ksiąskiej został Andrzej Tęczyński, dawny zwolennik husytyzmu. Poza tym słynny on był z tego, że trwonił pieniądze, że żył uwikłany w długach i miał bardzo pobudliwy charakter. Ta ostatnia cecha sprowokowała nawet mieszczan krakowskich do zamordowania go w r. 1461.

Naprawdę poważnym zagrożeniem dla augustianów wielkoksiąskich okazała się reformacja, która pojawiła się w Polsce pod koniec 1. połowy XVI wieku. Ten moment krytyczny dla klasztoru nastąpił wówczas, gdy Książ Wielki dostał się w ręce Jana Bonera, popularnego w Małopolsce kalwina, jako wiano jego żony Katarzyny z Tęczyńskich. Boner nie mógł od razu zaprowadzić w Książu kalwinizmu, dopóki mianowicie żyła jego teściowa Katarzyna Tęczyńska, którą łączyła głęboka więź z katolicyzmem. Gdy umarła w r. 1558, wówczas usunął z miasta duchowieństwo świeckie i klasztorne, a następnie zagarnął jego majątek.

Augustianie zatem dopiero wtedy mogli tutaj powrócić, gdy dobra wielkoksiąskie zakupił w r. 1582 biskup krakowski Piotr Myszkowski. Po dokonanej rewindykacji zniszczonych już zabudowań nie udało się im wejść jednocześnie w posiadanie wszystkich gruntów, łąk i ogrodów, jakie dawniej otrzymywali. O zwrot tego majątku musiał konwent wytoczyć proces Adamowi Bonerowi, dziedzicowi Mianocic, który trzymał go kurczowo w swoim ręku.

Wstępnym krokiem konwentu na drodze dochodzenia swoich praw majątkowych była relacja dokumentu fundacyjnego do wielkoksiąskich akt ziemskich w dniu 15 stycznia 1599 r. Dokonał jej ówczesny przeor tutejszego konwentu Maciej Karski przedłożywszy autentyczny dokument. Następnie o zabrane grunta wszczęli augustianie proces w powiatowym sądzie ziemskim w Książu Wielkim, jednakże ten spór został definitywnie rozstrzygnięty dopiero przez trybunał w Lublinie. Woźny sądowy Marcin Przezwocki z Tochołowa podał wówczas relację do akt grodzkich w Krakowie 23 czerwca 1611 r. o wejściu w posiadanie przez konwent gruntów spornych. W końcowym etapie tego sporu reprezentował miejscowy klasztor przeor Marek Słupski. Gdy zaś wcześniej, w roku 1598 Krzysztof Kazimierski, archidiakon krakowski, wizytował Książ Wielki, to okazało się, że tutejsi eremici św. Augustyna mieli już przywrócone dochody z młyna wójtowskiego.

Wiek XVII był dla tychże eremitów okresem dalszego wzrostu majątku. Był to okres wzmożonej religijności, zarazem dobą tzw. reakcji katolickiej, co w rezultacie przyniosło klasztorowi ksiąskiemu świeże darowizny i jałmużny. Przyjmując je, brał klasztor na siebie obowiązek odprawiania modłów za dusze ofiarodawców. Zwłaszcza w drugiej połowie tego stulecia, miejscowi zakonnicy otrzymali tych ofiar najwięcej.

W dniu 22 czerwca 1654 r. Wojciech Pestkowski, rodem z Książa Wielkiego, oddał na własność miejscowemu klasztorowi dom z ogrodem na tzw. Dołku, czyli przy gościńcu do Miechowa, naprzeciwko konwentu augustianów. Prócz tego dodał jeszcze kawał pola na Wodącej, które z jednej strony grani- 
czyło z łąką klasztorną, a następnie swoją dłuższą krawędzią dotykało strumyka, wypływającego z tutejszego źródła. Akt swej darowizny sporządził Pestkowski w urzędzie radzieckim miasta Kazimierza koło Krakowa. Jedną z przyczyn jego hojności dla klasztoru był syn Walenty, który przybrał imię Józefa, wdział habit tego zakonu i zamieszkał w jego murach.

Bogatą jałmużnę otrzymał klasztor 18 stycznia 1663 r. z rąk Anny Mohylanki dla ratowania duszy jej zmarłego męża Władysława Myszkowskiego, dziedzica Książa Wielkiego. Zapis ów wynosił dwa tysiące florenów polskich. Pieniądze te wypożyczał od konwentu Mikołaj z Przeręb Przerębski, starosta tuszyński, i zawarował je w aktach grodzkich na wsiach Rędziny i Wyczerpy w powiecie lelowskim. Na tym właściwie urywają się większe darowizny dla ksiąskiego klasztoru ze strony dziedziców miasta. Odkąd zresztą dobra Myszkowskich zostały objęte ordynacją w 1601 r., augustianie nie mogli się od nich spodziewać nadania im jakiegokolwiek działu ziemi.

W czerwcu 1688 r. urodzony Melchior Pachowski, dziedzic wsi Janikowice w powiecie proszowickim, zeznał osobiście w urzędzie grodzkim Krakowa, że zobowiązał się wypłacać przeorowi i konwentowi w Książu Wielkim 70 florenów polskich tytułem rocznego czynszu od sumy kapitalnej 1000 florenów. Tę sumę wypożyczył Pachowskiemu Tomasz Bielecki, dziekan jędrzejowski i proboszcz mieronicki, aby ufundowal jedną mszę św. w tygodniu za dusze cierpiące w czyśćcu.

W maju 1691 r. Sebastian i Katarzyna Lescy zapisują z kolei klasztorowi ksiąskiemu 70 florenów za jedną mszę św. co sobotę. Ten czynsz miał wypłacać urodzony Sebastian z Dobni Dobiński za wypożyczone od nich 1000 florenów, zagwarantowane na jego wsi Gniewięcin w powiecie ksiąskim.

Niebawem 600 florenów polskich zapisał też dla konwentu urodzony Marcin Limiński, właściciel gruntów na przedmieściu Miechowa. Za obopólną zgodą syna i córek dokonał tej legacji w aktach miechowskich 14 lipca 1693 r.

Inna bogata darowizna dostała się augustianom 6 października 1698 r., gdy Marcin z Kotarzyna Kotarski, podstarości i sędzia grodzki chęciński, ofiarował im folwark na Głogowianach z dwoma zagrodnikami, łąkami i browarkiem ażeby liczba księży w klasztorze powiększyła się o dwóch i aby codziennie odprawiano mszę za jego duszę. Jednocześnie zobowiązał Kotarski augustianów wielkoksiąskich do corocznego dawania $\mathrm{z}$ tego folwarku franciszkanom $\mathrm{z}$ Nowego Korczyna 50 florenów i dziesięciu ćwierci pszenicy. Gdyby ostatni obowiązek wydawał się miejscowemu konwetowi za ciężki, wówczas mógł on jednorazowo dać tym franciszkanom 2000 florenów. Łącznie z majątkiem nieruchomym otrzymali bracia pustelnicy sprzęt gospodarczy (pługi, 12 wołów), a w browarze naczynia do warzenia piwa, które mogli wytwarzać wyłącznie na własny użytek.

U progu XVIII wieku spadły na klasztor wielkoksiąski nieszczęścia „wojny północnej”. Zakonnicy doznali wtedy poważnych strat w ludziach i majątku, 
o czym pisał będący na wizytacji w Książu prowincjał Hieronim Schmidt w jednym ze swych listów, w którym ubolewał nad prowincją augustianów w Polsce, zniszczonej przez wojnę i zarazę. Wizytacja ta odbyła się w kwietniu $1710 \mathrm{r}$. Mówiąc o zniszczeniach wojennych miał tu między innymi na myśli wizytator Schmidt zwaloną część kościoła św. Ducha. Lustracja konwentu w następnym roku pozostawiła protokól o podobnej treści na temat wyrządzonych klasztorowi zniszczeń przez działania wojenne. Większe fundusze na odbudowę zniszczonego kościoła złożył wówczas kasztelan radomski Morsztyn, a oprócz niego Kotarski.

Jeszcze nie przebrzmiały w pamięci klasztoru straszliwe skutki niedawnych nieszczęść wojennych, gdy tymczasem zjawiły się już nowe. W $1741 \mathrm{r}$. uległ groźnemu pożarowi kościół św. Ducha, a wraz z nim otaczające go zabudowania. Wydatną pomoc dotkniętemu katastrofą klasztorowi okazało wówczas wiele osób. Przede wszystkim imię dobrodzieja pozyskał tu sobie Jan Mietelski, archidiakon tarnowski i proboszcz małoksiąski. Ofiarował on w różnych odstępach czasu ponad cztery tysiące florenów polskich na restaurację kościoła św. Ducha. Wzruszony hojnością Mietelskiego prowincjał augustianów poleca ksiąskiemu konwentowi odprawiać mszę św. za duszę tak znakomitego ofiarodawcy. Prawdopodobnie wówczas w miejsce dawnego drewnianego budynku klasztornego wzniesiono murowany, chociaż potwierdzenia tego faktu nie znajdujemy w dostępnych nam źródłach.

Wyniszczeni gospodarczo przez pożar augustianie odgrzebują z pyłu archiwalnego dokumenty starych nadań, ażeby znaleźć podstawę do ściągania należnych, lecz przez reformację przerwanych powinności. W jednej z wydobytych ksiąg wyczytano, że klasztorowi należy się z dworu margrabiego „14 korców [...] jęczmienia, 18 owsa, 6 pszenicy", a oprócz tego w każdym miesiącu po 12 florenów dzierżawy, bliżej nie określonej. Na podstawie aktu fundacyjnego domagał się więc klasztor, aby dwór dawał mu połowę dochodów z młyna.

W dniu 18 stycznia 1756 r. doszło do zawarcia interesującego aktu między pustelnikami św. Augustyna w Książu Wielkim a niewiernymi (żydami) z sąsiedniego Wodzisławia. Przed urzędem wójtowskim, radzieckim i ławniczym w Wodzisławiu „oblicznie przyszedłszy niewierni żydzi [...] jawnie, jaśnie [...] imieniem całego pospólstwa [...] dobrowolnie zeznali”, że za zgodą dziedzica miasta hr. Stanisława Lanckorońskiego pożyczają od konwentu ksiąskiego tysiąc florenów na „wyderkaff”, czyli na wykup. Te floreny brali Żydzi wodzisławscy „na własną potrzebę całej synagogi” i jako czynsz zobowiązywali się dawać po 35 złotych polskich rocznie na dzień św. Agnieszki, panny i męczenniczki, bez żadnej zwłoki. Gdyby kahał z Wodzisławia nie dotrzymał swoich zobowiązań, wówczas augustianie mieli prawo zapieczętować im bóżnicę i wszystkie sklepy. Jeśliby to nie poskutkowało, „wolno będzie” konwentowi ksiąskiemu urzędowo lub prywatnie brać każdego Żyda z Wodzisławia, a następnie osadzać go w więzieniu. Nie tylko w Wodzisławiu mogą ich zabierać, ale również 
po jarmarkach w innych miasteczkach, a nawet w samym Krakowie. Pojmani Żydzi tak długo mają przebywać w więzieniu, dopóki nie wywiążą się ze swoich zobowiązań. Augustianie zastrzegli sobie jeszcze w owym dokumencie, że uwięzieni Żydzi muszą się utrzymywać własnym kosztem.

Proboszcz Adam Brachman, który tak szczodrą rękę okazał dla wielkoksiąskiej szkoły i dla kościoła parafialnego, powiększył również dochody miejscowego klasztoru. W dniu 21 lipca 1769 r. zapisał on dla niego, w aktach krakowskiego grodu, czynsz od 1000 florenów polskich. Tą sumą, od której mieli brać augustianie $5 \%$ odsetek w stosunku rocznym, obciążył Brachman swoją wieś dziedziczną Dąbrówkę, położoną w powiecie lelowskim. Ze swej strony zobowiązał się konwent odprawiać corocznie kilka mszy za dusze zmarłych rodziców ofiarodawcy - Franciszka i Teresy Brachmanów. Na akcie tym, wystawionym przez Brachmana, kończą się właściwie zapisy podobnych funduszów dla klasztoru.

Gdy duch wzmożonej religijności zachęcał kiedyś wiernych do tego rodzaju fundacji, to również z tą chwilą, kiedy w Polsce powiał wiatr racjonalizmu wieku Oświecenia, przygasła także i większa troska o szczęście wiekuiste, a jednocześnie urwały się bogate czynsze. To zahamowanie mogło być w pewnym stopniu wynikiem niespokojnych czasów, w jakich żyła Polska, rozszarpywana przez sąsiadów.

W r. 1795 dawna Rzeczpospolita Polska dostała się ostatecznie w ręce zaborców; Książ Wielki znalazł się najpierw w granicach monarchii austriackiej. Jednym z aktów rządu wiedeńskiegó, jaki dał się dotkliwie odczuć klasztorowi ksiąskiemu, była częściowa konfiskata majątków kościelnych. Wtedy stracili tutejsi augustianie folwark na Głogowianach i część otrzymywanych dawniej czynszów. Opis beneficium klasztornego z r. 1801 wyszczególnia, że do klasztoru należało 140 morgów i 103 pręty. Ten stan posiadania zmniejszył się jednak na przestrzeni lat 1818 - 1842 do 124 morgów i 135 prętów. To skurczenie się areału klasztornego można wytłumaczyć tym, że znaczny szmat pola został zagarnięty augustianom pod budowę szosy.

Według spisu gruntów z 18 lipca 1842 r. do augustianów należało 11 morgów 1217 sążni pola na Wzorku, 9 morgów 1241 sążni łąki przy ogrodach miejskich, 1396 sążni łąki, zwanej „,suchą”, 1 mórg 200 sążni ogrodu nad rzeką koło miasta, 500 sążni ogródka i sadu przy klasztorze, 856 sążni pastwiska koło folwarku oraz pole, zwane „zabrzeźne”, gdzie samych parowów było blisko 9 morgów. W mieście Książu miał jeszcze konwent 2 place, które nabył przeor Mysłowski po pogorzeli: jeden znajdował się obok cmentarza, a drugi przy klasztorze. To samo źródło podaje również, że augustianie ksiąscy pobierali jeszcze wtedy każdego roku procenty z Kasy Obwodowej w wysokości 71 zł 10 gr, ze wsi Kowale od 1000 zł odsetek 40 zł i z kamienicy Mohra w Krakowie 50 zł, czyli razem 161 zł 10 gr. W owym czasie liczył też klasztor 4 zagrodników, których osadził na 4 morgach 1840 sążniach. 


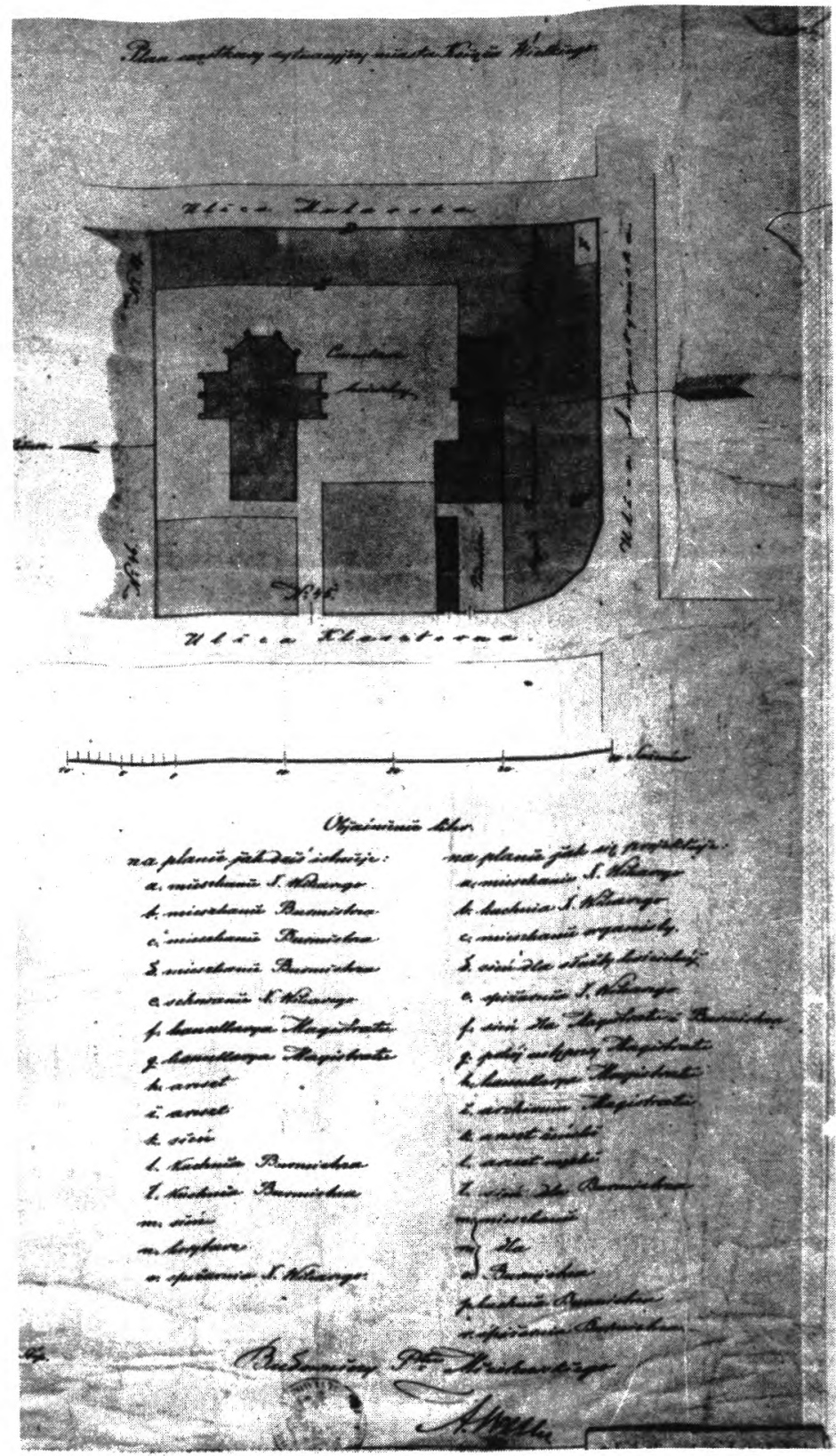

1. Częściowy plan Książa wielkiego, wykonany w roku 1866 przez Alfonsa Welkego, budowniczego powiatu miechowskiego (AGAD).

Po pożarze w 1836 r. klasztor wielkoksiąski znalazł się znowu w ciężkiej sytuacji gospodarczej. Wypalił się prawie doszczętnie kościół św. Ducha zew- 
nątrz i wewnątrz. Zgorzały sąsiadujące $\mathrm{z}$ kościołem dzwonnica, klasztor oraz zabudowania gospodarcze. Pod kierunkiem przeora Mysłowskiego rozpoczęto wprawdzie odbudowę kościoła i klasztoru, ale roboty szły powolnym krokiem.

Po śmierci przeora Mysłowskiego w 1841 r., do Książa przybył prowincjał Adeodat Buczkiewicz, który energicznie przystąpił do kontynuowania odbudowy. Pieniądze na odbudowę kościoła zbierano nie tylko między okoliczną ludnością. Kwestarze klasztoru dotarli nawet do Warszawy i tam nie pominięto nawet pałacu księcia Paszkiewicza. Ostatecznie jednak klasztor został dźwignięty $z$ upadku, ale podczas tej odbudowy zatracił on swe pierwotne cechy architektoniczne na skutek dokonanych zmian i różnego rodzaju przeróbek. I tak pokryte gontem szczyty dachu uległy załamaniu przechodząc w naczólki. W niektórych zaś pomieszczeniach klasztornych znalazły się małe sklepienia krzyżowe. Sam budynek klasztorny został częściowo podpiwniczony. Według danych z wizytacji bpa Kochańskiego w r. 1783, klasztor wielkoksiąski miał sześć cel, jedno forysterium i korytarzyk. Wszystkie izby były wówczas sklepione.

Ostatnim użytkownikiem zachodniej części budynku klasztornego była kancelaria książskiego magistratu. W latach późniejszych prawie cały budynek oddany został na użytek szkoły, która egzystowała tam do r. 1937.

\section{KOŚCIÓŁ ŚW. DUCHA}

Kościół poaugustiański pod wezwaniem św. Ducha był budowany przez Jana Melsztyńskiego po r. 1371 i ukończony najpóźniej w 1380. Został on skierowany wielkim ołtarzem ku wschodowi. Architektura tej niewielkiej świątyni musiała przy tym posiadać dość znaczne wartości artystyczne, skoro Jan Długosz pisał, że Jaszko z Melsztyna ufundował klasztor w mieście Książu i budował kościół o pięknych murach i sklepieniu.

Prawdopodobnie do budowy tego kościoła dla augustianów zaangażowany został przez dziedzica miasta Janko „lapicida”, czyli kamieniarz z Książa, o którym jest zapiska w księgach sądowych powiatu wielkoksiąskiego. Czytamy w niej, że 28 lutego 1377 r. miał on proces z trzema kmieciami. Jednocześnie warto wyjaśnić, że wyraz „lapicida” oznaczał dawniej nie tylko kamieniarza, lecz również budowniczego, architekta i rzeźbiarza. Być może ów Janko, kamieniarz z Książa, wykuwał tutaj swoim dłutem ozdobne elementy dla budowanego augustianom kościoła. Poza tym nic nie wskazuje na to, aby wówczas mógł on być zatrudniony w Książu Wielkim przy jakiejś innej budowie.

Kościół św. Ducha w Książu Wielkim u progu swego istnienia był gotycki i zapewne mógł na siebie zwrócić uwagę delikatnymi liniami architektury swojego stylu i wykładziną ścian wewnętrznych. Do chwili obecnej nie znaleziono jednak żadnego śladu wyposażeń wewnętrznych tego kościoła, choć trzeba 
przy tym wspomnieć, że do dnia dzisiejszego nie było możliwości gruntownego przebadania tego zabytku.

Ówczesny kościół był znacznie wyższy od dzisiejszego, ponieważ gotyk miał dachy wysokie i strome. Jednocześnie podniósł się poziom gruntu otaczającego kościół, na co składały się podsypki z odbudowy i remontów. Obecnie podmurówka kryje się w ziemi na głębokości około $60-85 \mathrm{~cm}$. Również przypadkowo odkryte okienka w ścianie południowej i północnej nawy, spełniające dawniej rolę wentylatorów podziemi, też są zaniżone blisko $30 \mathrm{~cm}$. To „opadnięcie" kościoła jest także widoczne w poziomie posadzki w prezbiterium i nawie - około $40 \mathrm{~cm}$, a w starej zakrystii — około $50 \mathrm{~cm}$.

Przy nawie kościół gotycki miał szkarpy, podobnie jak dzisiaj przy prezbiterium, czego śladem mogą być dwie podmurówki, przypadkowo odkryte, o przekroju poziomym $45 \times 50 \mathrm{~cm}$. Te pionowe kontury szkarp, przegradzane wysokimi oknami, musiały łącznie $\mathrm{z}$ wysokim dachem i strzelistą wieżyczką tworzyć piękną sylwetkę gotyckiego kościoła w Książu Wielkim.

Po opuszczeniu miasta w 1558 r. przez duchowieństwo katolickie gospodarzami kościoła parafialnego i klasztornego byli najpiew kalwini, a potem arianie. W 1562 r. umiera Boner, zwolennik reformacji, a po nim dziedzicem miasta zostaje wojewoda krakowski Stanisław Barzy, gorliwy katolik. Po usunięciu zatem innowierców doszło najpierw do restytucji kościoła parafialnego. Gdy kilka lat potem (1565) wizytował Książ Wielki bp Padniewski, miejscowy klasztor przedstawiał obraz wielkiego zniszczenia.

Jeśli chodzi o kościół św. Ducha, to zapewne po usunięciu stąd zakonników stał on opustoszały i popadł w ruinę. Gdy po czterdziestu latach od momentu ich wyjścia z Książa zjawił się tu, na polecenie kard. Radziwiłła w r. 1598 archidiakon Krzysztof Kazimierski, wówczas stwierdził w protokole, że w mieście jest kościół pusty, murowany, pod wezwaniem św. Ducha. Obok tego kościoła był też klasztor drewniany, który również został spustoszony przez heretyków... Należy dodać, że w czasie tej wizytacji Kazimierskiego, nie było jeszcze w Książu Wielkim augustianów, ponieważ miejscowy proboszcz pobierał dziesięcinę ze wszystkich gruntów klasztornych.

Biskup krakowski Piotr Myszkowski nabył Książ Wielki w 1582 r. i zwrócił zakonnikom ich majątek w mieście. Nie od razu jednak mogli zakonnicy objąć go w posiadanie, gdyż według słów o. Augustyna Kalsiusa w liście do generała zakonu nie nadawal się on do zamieszkania z powodu zniszczenia. Dopiero po intromisji augustianów 22 czerwca 1611 r. na grunta w Brzezinkach i na Podbrzeziu oraz po rewindykacji różnych czynszów mógł konwent wielkoksiąski przystąpić do odbudowy czy naprawy swoich budynków.

Wiele doznały cierpień od Szwedów polskie miasta i miasteczka w czasie najazdu, zwanego potopem. Wtedy i Książ Wielki został przez nich zniszczony pożarem. Jakich spustoszeń dokonał wtedy żywioł ognia, jak konwent augu- 
stianów przetrwał okupację szwedzką, na to trudno w tej chwili znaleźć odpowiedź.

Lustracja ksiąskiego konwentu z 30 października 1711 r. informuje w protokole, że jego kościól miał chór mniejszy murowany, natomiast większy był również murowany, lecz runął z powodu starości. Czytamy dalej, że fundamenty zostały już założone pod nowy kościół dzięki pomocy kasztelana radomskiego Franciszka Morsztyna, dziedzica Mianocic, i Marcina Kotarskiego, który był podstarościm i sędzią grodu chęcińskiego.

Dużo wysiłku kosztowała ta odbudowa z powodu długich wojen, grabieży, upadku gospodarczego i epidemii. Nic więc dziwnego, że do jej ukończenia potrzeba było wielu lat mozolnej pracy. Tymczasem jeszcze nie zdążyły się ulotnić z pamięci miejscowych augustianów te ciężkie lata trudów przy odbudowie, gdy niespodziewanie pewnego dnia w 1741 r. płomień ogarnął kościół wraz z zabudowaniami klasztornymi i całkowocie je spalił.

Tym razem znowu konwent wielkoksiąski przystąpił z miejsca do odbudowy zniszczeń. Najlepszym gospodarzem przy tej odbudowie kościoła i klasztoru okazał się Tomasz Wóycikiewicz STB, który był tu przeorem (z wyboru na kapitule w Lublinie w latach 1743 - 1749), choć właściwie już przeor poprzedni Klemens Penquitt, za którego rezydencji klasztor doświadczył tragicznych skutków pożaru, zaczął sprowadzać materiały budowlane. Najpierw najął cieślów do pracy przy kościele, ażeby budową prowizorycznego dachu uchronić stropy przed zniszczeniem.

Dalszą zwózką budulca względnie na miejscu jego produkcją zajął się jego następca, przeor Wóycikiewicz. Najpierw po gonty wysyłał furmanki do Krzelowa lub Gniewięcina, ale gdy nie mógł zakupić odpowiedniego materiału, sam prowadził ich wyrób. To samo było z tarcicą i z początku kupowạł ją w Marcinowicach, Przełaju czy Dobrakowie, a potem kilku traczów miał przy sobie, co bardziej usprawniało jego pracę. Cegłę od samego początku wyrabiano w pobliżu Książa i tą sprawą zajmował się tutaj „magister” strycharz ze swoim pomocnikiem. Okucia budowlane, gwoździe gontowe, bretnale, szkło do szyb można było kupować na jarmarkach w Mysłowicach. Pan tego miasta Miroszewski, starosta siewierski, sprzedawal klasztorowi z Książa Wielkiego żelazo kowalne ze swojej kuźnicy. Drogą pośrednią nabywano również wyroby kowalskie z Tarnowskich Gór. Mniejsze ilości gwoździ gontowych kupowano w Olkuszu lub w Krakowie. Jedyny raz kupował klasztor szyny żelazne w kuźnicy koło Pilczy (dzisiaj Pilica).

Pierwszym śladem powiązań przeora Wóycikiewicza z krakowskim mistrzem (magistrem) cieślą w sprawie roboty „fabrycznej” kościoła w Książu Wielkim była wypłata zaliczki 1 grudnia 1744 r. Później okazało się, że do prac budowlanych został zaangażowany popularny już wówczas mistrz ciesielski Piotr, noszący nazwisko Bober. Miał on do pomocy podmajstrzego Urbana 
z Krakowa i czterech mniej kwalifikowanych cieślów, których liczbę powiększał czasem piąty - nazwiskiem Wrzesień.

Dach na klasztorze miał wykonać Wawrzyniec Górski, jednak pracę tę oddano mistrzowi ciesielskiemu Kawie z Olkusza. Gdy chodziło o robotę bardziej skomplikowaną, to wtedy przeor powierzał ją wyłącznie cieśli Piotrowi i w dodatku pisał z nim jeszcze kontrakt. Tak np. 15 lipca 1746 r. została z tym majstrem zawarta umowa, która dotyczyła budowy kopuły na kościele, obicia jej blachą i wmontowaniu na niej krzyża i złocistej „bani”. Ta sama umowa odnosiła się do pokrycia prezbiterium, które musiało mieć skomplikowaną więżbę dachową. Warto dodać, że na podstawie tej umowy przeor zapłacił za wykonane prace 200 złotych. Tę „banię” do kopuły, przypuszczalnie na wzór zniszczonej z poprzedniego kościoła, zrobił kotlarz Ferdynand z Krakowa za 8 florenów, przy czym jej pozłocenie kosztowało tyle samo. Ażeby upamiętnić dzieło odbudowy kościoła, jeden z księży napisał odpowiednią „erekcję”, którą w małej poszewce schowano do bani.

W czasie pożaru ogień uszkodził facjatę ściany frontowej i spowodował opadnięcie ankrów na sklepienie. Remont trójkątnej facjaty zakończył się przybiciem do niej gzymsów, do czego potrzeba było piętnaście wielkich gwoździ. Miejscowy kowal przywrócil ankrom potrzebny poziom.

Przed głównym wejściem od zachodu stała kruchta drewniana, zbudowana na węgieł i gontem pokryta. Podobna kruchta znajdowała się przed wejściem południowym. Każda z nich miała wejście zamykane.

W tęczy, czyli między prezbiterium a nawą była belka, w środku wypukła do góry, wsparta przy ścianach na drewnianych pilastrach. Na belce tej stał w środku krucyfiks, a obok niego była M. B. Bolesna i św. Jan Ewangelista. Ta belka tęczowa $\mathrm{z}$ figurami była ozdobiona czerwienią $\mathrm{z}$ fernambuku i dekoracją snycerską, którą pokryto srebrem w r. 1749.

Budowa chóru zakończyła się wiosną 1751 r. Został on pokryty farbą szafirową z imitacją marmuru. Już w lutym tego roku stał na tym chórze tzw. pozytyw z dziesięcioma głosami i z dokonaną korektą głosów. Trudno też nie wspomnieć o tym, że na pozytyw ten wydał 900 zł z własnej kieszeni ks. Jan Mietelski, archidiakon tarnowski i prałat małoksiąski, oraz że dzięki niemu chór ten został wykończony.

Stalle dla oo. augustianów, według relacji wizytatora, znajdowały się w prezbiterium i odznaczały się „starą strukturą i malowaniem”. Archidiakon Kochański snuł przypuszczenia, że sięgały one jeszcze czasów fundacji klasztoru.

Do cennych zabytków sztuki snycerskiej połowy XVIII stulecia musiała należeć w kościele św. Ducha nie istniejąca już dzisiaj ambona. Na tle ścianek tej mównicy ustawił anonimowy dziś dla nas snycerz cztery figurki ewangelistów, natomiast baldachim tej ambony ozdobił ornamentem $\mathrm{z}$ kwiatów i postać św. Jana Chrzciciela z barankiem. $\mathrm{Z}$ wyjątkiem białych figurek, które miały pozła- 
cane gwenty, i posrebrzanej dekoracji kwiatowej, reszta ambony utrzymana była w kolorze szafirowym.

Ławki stojące w kościele dwoma rzędami miały prawdopodobnie duże walory stylowe i artystyczne. Przede wszystkim nietrudno doszukać się w opisie ich stylu. Te pełne dynamizmu linie, te boki „puklaste z przodu i z tyłu” wskazują na styl rokoka. „Wyrzynania” obustronne na poręczach, na które zwrócił uwagę archidiakon Kochański, można wziąć za dowód bogatej dekoracji.

Historia ołtarza głównego jest nieco dłuższa. Najpierw przeor Wóycikiewicz pojechał do Szańca w listopadzie 1744 r., ażeby odebrać obraz z rąk koniuszyny koronnej Elżbiety z Mniszchów Wielopolskiej, żony Karola, dziewiątego ordynata. Koszt budowy ołtarza i jego malowania w dużej części pokrył szlachcic Żuliński zza Skalbmierza. Malowanie ołtarza głównego z mensą i jednocześnie tęczy, a potem ozdabianie tych przedmiotów złotem i srebrem przeciągnęło się do roku 1749. Do tych prac przywożono malarza z Jędrzejowa. Kochański widział w ołtarzu głównym szafiastą „strukturę”. Był on malowany wtedy na kolor szafirowy, podobnie jak i inne przedmioty. Znajdowal się w nim obraz Najświętszej Panny Marii Pocieszenia. Chociaż wizerunek był na płótnie, to jednak Matka Boska miała malowaną suknię z drewna, z oznakami starości. Na głowach Matki Boskiej i Dzieciątka Jezus błyszczały złocone korony ze srebra. Obraz ten nakrywała zasuwa z Zesłaniem Ducha Świętego. Po bokach głównego ołtarza stały dla ozdoby figury snycerskiej roboty.

W r. 1751 augustianie przystąpili do budowy dwóch ołtarzów bocznych, na co proboszcz małoksiąski Jan Mietelski podarował znowu 900 złotych. Ołtarze te zdecydowało się ozdobić dwóch „magistrów” snycerzy i jeden malarz. Jednak przy wypłacie należności przemilczano zupełnie ich personalia. Pominięto również tak ciekawą sprawę, jaką tematykę pragną mieć zakonnicy na zamówionych obrazach. Najwięcej szczególów w opisie ołtarzów bocznych pozostawił archidiakon Kochański w protokóle wizytacyjnym z 1783 r. Według jego relacji, po prawej stronie nawy jako drugi z kolei (po ołtarzu głównym) wznosił się ołtarz św. Augustyna. W górnej kondygnacji zdobił go obraz św. Moniki. Ołtarz był „stolarską strukturą wystawiony i snycerską robotą ozdobiony, w marmur malowany, a w rzeźbie wysrebrzany i wyzłacany miejscami". Po przeciwnej stronie nawy znajdowal się ołtarz św. Mikołaja z Tolentynu. W jego szczytowej części umieszczono wizerunek bł. Wincentego Kadłubka. W budowie, dekoracji i malowaniu niczym się nie różnił od ołtarza przed nim opisanego.

Po prawej stronie nawy stał ołtarz św. Tekli. W górze był ozdobiony obrazem św. Anny. Ten oltarz w kościele św. Ducha uchodził za staroświecki, następnie tym zwracał na siebie uwagę, że cały był we „floresy rznięty, na czarnym malowaniu, marcypanowo złocony i wysrebrzany" a mensę miał murowaną. Ołtarz św. Antoniego miał na zwieńczeniu obrazek św. Tekli na tle obło- 
ków i promieni, poza tym był wystawiony „strukturą stolarską" i cały szafirowo malowany.

Wielki obraz z zesłaniem Ducha św. wisiał na ścianie. Miał on ramę podobną do ołtarza, którą zdobiła snycerska robota. Kościół posiadał też feretron, wykonany ręką snycerza. W ramę tego feretronu oprawiono dwa obrazy, malowane „pod laserunek” - Matki Boskiej Pocieszenia i św. Anny. Obraz św. Tekli kontrastował swoim kolorem i formą z resztą wyposażenia kościoła. Tymczasem pozostałe ołtarze były zharmonizowane kolorem szafiru, na którego tle delikatnie rysowała się srebrzona i złocona ornamentacja.

Zakrystia, po lewej stronie nawy, w czasie wizyty Kochańskiego była nadal w stanie użytkowania. W niej przechowywało się wtedy krucyfiks na procesje, znajdowały się tutaj sżafy na ornaty i kapy, mensa do ubierania się oraz wielka skrzynia na „szczupłą” argenterię (wyroby ze srebra i złotnicze).

Cały kościół był pokryty gontami. Gdy od zachodu wjeżdżało się na dziedziniec klasztoru dwuskrzydłową bramą, wówczas z lewej strony mijało się dzwonnicę w kształcie wieży (z 1743 r.). Była ona obita tarcicami i miała daszek z gontów. Wisiały w niej dwa dzwony średniej wielkości. Dodajmy, że wokół cmentarza tego kościoła stał parkan, nakryty daszkiem z gontów. Urwiste zaś brzegi od wschodu, południa i zachodu utrudniały znowu dostęp do klasztoru, który od strony południowej miał małe podwórko i trochę budynków gospodarczych.

Wydatną pomoc dotkniętemu katastrofą konwentowi augustianów w Książu Wielkim okazało wiele osób, z których kilka wskazać należy przykładowo. Zwłaszcza więc Karol i Elżbieta z Mniszków Wielopolscy, dziedzice Książa Wielkiego, przekazali na ręce miejscowego przeora relikwiarz i obraz dla klasztornego kościoła, poza tym wpłacali dukaty i floreny polskie. Na budowę tę wpłacali również większe datki niektórzy mieszczanie z Książa Wielkiego. Jednym z nich był sławetny burmistrz Sebastian Brylski, jednocześnie długoletni cechmistrz „kunsztu” szewskiego. Ofiarował on 100 złotych na kupno lampy przed ołtarz. Inny zaś mieszczanin, mianowicie sławetny majster krawiecki Rudlicki dał mantolet z zielonego adamaszku, dokupił też materiału za 40 złotych i uszył z niego kapę dla kościoła.

Wysiłek wielu ludzi i wielu lat, mimo burzliwych czasów upadku gospodarczego, politycznego i moralnego, zakończył się dużym sukcesem dla augustianów wielkoksiąskich, gdyż kościół i klasztor oraz całe obejście otrzymały pożądany wygląd. Należy tylko żałować, że ten zabytek kultury narodowej na prowincji, całkowicie odbudowany, $\mathrm{z}$ ciekawym wyposażeniem wnętrza nie doczekał naszych czasów. W dniu 5 sierpnia 1836 r., zaraz po południu, wybuchł wielki pożar w Książu Wielkim. Spłonęło wtedy pięćdziesiąt domów i sześćdziesiąt rodzin zostało bez dachu nad głową. Pożar w tym dniu nie ominął też kościoła św. Ducha, klasztoru i dzwonnicy. Z płomieni zdołano uratować jedynie kilka obrazów, figurek, naczyń liturgicznych. Reszta cennych zabytków 
uległa zniszczeniu. Podobnie 21 sierpnia tego samego roku miejscowym augustianom spaliły się znowu na folwarku Podbrzezie wszystkie zabudowania łącznie z inwentarzem. W sumie poniósł wtedy miejscowy konwent olbrzymie straty.

Brzemię odbudowy spadło z kolei na barki przeora Kaspra Wojciecha Aurelego Mysłowskiego. Borykanie się o potrzebne fundusze i materiały przerastało jego możliwości. Nic też dziwnego, że odymione mury kościoła i klasztoru stały bez mała przez pięć lat ruderą, nakryte jedynie słomą. W dużej mierze przyczyniła się do tegoż choroba samego przeora, a potem jego śmierć w $1841 \mathrm{r}$.

W czasie swojej wizytacji 20 kwietnia 1841 r. w Książu Wielkim prowincjał augustianów Adeodat Buczkiewicz postanowił osobiście zająć się odbudową spalonych obiektów klasztornych. Wtedy też z ubolewaniem stwierdził, że kościół św. Ducha na przestrzeni ostatnich stu lat został dwukrotnie spalony zewnątrz i wewnątrz. Ażeby mieć dokładny obraz gospodarki funduszami, materiałami i siłą roboczą, zaprowadził dokładny „rejestr fabryki przy kościele oo. augustianów w Książu Wielkim", poza tym podpisał z majstrami umowy, które zobowiązywaly ich obustronnie.

W kontrakcie zawartym 24 marca 1841 r. zobowiązywali się majstrowie murarscy, obywatele Książa Wielkiego: Jan Ziółkowski i Maciej Płonczyński, likwidować zniszczenia i budować. Ten dokument o tyle był ciekawy, że dawał między innymi rozeznanie, jakie szkody wyrządził pożar w murach kościoła i jakie zmiany zaszły w jego architekturze. Majstrowie zobowiązywali się też wystawić „przedsionek” (później nowa zakrystia) przy południowym wejściu z klasztoru do kościoła, z pięknym sklepieniem, wejściem i jednym dużym oknem od wschodu. Na jego północną i zachodnią ścianę wykorzystano ściany kościoła, a od wschodu - szkarpę. Fundament „przedsionka”, według zaleceń prowincjała, miał stanąć na prawdziwym gruncie. Majster Ziółkowski podjąl się nadmurować facjatę frontową i środkową, używając do tego cegły. Potem, zgodnie z planem budowniczego z Miechowa, nakładał na cegłę przygotowane do tego płyty kamienne (z Pinczowa). Na środkowej facjacie umieszczono sygnaturkę, mając nadzieję, że w przyszłości będzie można wystawić tutaj większą wieżę. Do wielkich drzwi frontowych, bocznych i do zakrystii, zobowiązali się majstrowie wstawić fugowane futryny kamienne. Do nich też należała naprawa gzymsów, pilastrów, wejścia na strych, dalej - oprawa belek pod chór i ambonę, zeskrobanie tynków wewnątrz i zewnątrz kościoła, a potem nałożenie nowych i wreszcie podwójne wybielenie.

Augustyn Jezierski, majster cieśla z Książa Wielkiego, wykonał dach na kościele i klasztorze, odpowiedzialny był za dobre ich pokrycie gontami. Jego dziełem był również chór w kościele. Majster stolarski Ksawery Mazur pozostawił też wiele prac po sobie: ambonę (bez figury św. Augustyna?), lawki na kościele i stalle. Wreszcie obróbkę ciosu w czasie restauracji powierzono sny- 
cerzowi Zaborowskiemu z Pinczowa, który pracował przy przebudowie pałacu Wielopolskich. Ponadto cieśle i stolarze wykonali drzwi, okna, szafy, podłogi oraz pewne prace w klasztorze.

Płyty kamienne na wykładzinę facjaty kościoła przywoziły furmanki z Pinczowa, gdzie materiał był już pocięty według podanych wymiarów. Wapno można było kupić w Sladowie lub w Kielcach, a szkło taflowe w Nowej Hucie za Małogoszczem. Gonty kupowali augustianie w Krzelowie, a drewno sprowadzano ze Słupi.

Ostatecznie, dzięki zainteresowaniu się odbudową energicznego prowincjała augustianów Adeodata Buczkiewicza, w pięć lat po pożarze klasztor dźwignięty został z upadku. Nie odzyskał już jednak tak pięknego wyglądu, jak przekazywały nam dawniejsze protokóły $\mathrm{z}$ wizytacji oraz inwentarz.

Dzisiejsze mury kościoła na skutek niefortunnych restauracji zatracily w znacznej części gotyckie kształty z XIV wieku. Dla zmniejszenia bowiem kosztów budowlanych oraz ujednolicenia zabudowy zaczęto na początku XIX w. opracowywać typowe projekty kościołów, zajazdów itp. Szablon klasycystycznej fasady otrzymali przeto i augustianie przy odbudowie kościoła św. Ducha.

Nad wejściem głównym znajduje się płaskorzeźba Niepokalanego Poczęcia NMPanny - czy jednak umieszczona została przy tej odbudowie, czy wreszcie sięgała czasów dawniejszych, dokładnie nie wiadomo.

Prezbiterium posiada tylko jedno przęsło i absydę zamkniętą trzema ścianami. Podniebienie jego sklepienia upiększają wiązania żebrowe ze zwornikami. Dzięki licznym krawędziom lukarn bogatszy jest też splot ścian w samej absydzie. Do wnętrza prezbiterium wpada rzęsiste światło przez wysokie okna o lekko załamanych łukach. Okna te były kiedyś znacznie wyższe niż dzisiaj, o czym świadczą ślady podmurowania ich od dołu. Po stronie zewnętrznej otwory okienne wykonano z kamienia ciosanego. Sciany prezbiterium wzmocniono zaś przyporami o dwóch okapnikach. Przypory te były niegdyś ozdobione gotyckimi kolcami. Po ścianie zewnętrznej prezbiterium przebiega mniej więcej w połowie wysokości gzyms gotycki.

Grube mury nawy dźwigają ciężkie, kolebkowe sklepienie, podzielone pasami na trzy przęsła, z których każde przy nasadzie ma po obydwóch stronach lunetę z oknem. Według przęseł, na sklepieniu zarysował się też przy pomocy zdwojonych pilastrów podział w każdej ścianie bocznej na trzy pola, przy czym w każdym z nich znajduje się wnęka, zamknięta u góry półkolistym gzymsem. Sciany nawy przedziela od sklepienia szeroki i głęboki gzyms. Elementy architektoniczne, jakie dostrzegamy w nawie mają cechy późnobarokowe.

Do ściany północnej prezbiterium przylega zakrystia, wzmocniona przyporami. Oświetla ją prostokątne okno w ścianie wschodniej. Przez gotyckie odrzwia, w górnej części fazowane (obecnie uszkodzone), wchodzi się na kamienne schodki w kształcie spirali, aby się dostać na strych kościelny. Do wnętrza klatki schodowej wpada światło przez trzy ostrołukowe okienka. Prosto- 
kątne zaś wejście z prezbiterium do zakrystii zamykają późnogotyckie drzwi z dwufalowym zamkiem, okute rozetkami i kratownicą z listew.

W czasie restauracji kościoła stanęła przy południowym boku prezbiterium jednopiętrowa dobudówka, którą przeznaczono na zakrystię i bibliotekę klasztorną. W tym również czasie na murze oddzielającym prezbiterium od nawy wzniesioną kamienną wieżyczką z sygnaturką. We wnętrzu kościoła musiano wstawić nowe ołtarze, a oprócz tego chór i ambonę.

W bibliotece przechowywany jest księgozbiór o treści religijnej, a niektóre jego tomy pochodzą jeszcze z XVI stulecia. Tutaj również przechowywany jest piękny krucyfiks. Sam krzyż i podstawa są z drewna, lecz Pan Jezus wykonany został z kości słoniowej, w stylu barokowym. Obecnie biel wapienna pokrywa wszystkie ściany wnętrza. Dawniej obok głównego ołtarza były stare malowidła ścienne, które wyobrażały św. Wojciecha i św. Stanisława. Na ścianie za ołtarzem św. Tekli przeziera przez wapno jakaś wielobarwna dekoracja, przypuszczalnie z XVIII wieku.

Główny ołtarz budzi w nas jedynie zainteresowanie późnobarokowym tabernakulum i obrazem N. Marii Panny. Popiersie Matki Boskiej, malowane na płótnie, wykonał, jak podają archiwalia klasztorne, artysta włoski z XVII w. Giovanni Battista Salvi, zwany również Sássoferrato (od miejsca swego urodzenia). Nie jest jednak rzeczą wykluczoną że mamy tutaj do czynienia tylko $\mathrm{z}$ kopią obrazu słynnego malarza, a nie $\mathrm{z}$ oryginałem. Obraz ten dostał się z Rzymu do Polski za pośrednictwem prowincjała augustianów Szymona Woynicza w r. 1793. Pierwszym miejscem pobytu obrazu w naszej ojczyźnie był klasztor augustianów w Krasnymstawie. Do Książa Wielkiego sprowadzil go znany już nam prowincjał Adeodat Buczkiewicz. Dnia 29 sierpnia 1841 r. obraz M. Boskiej został uroczyście umieszczony w głównym ołtarzu. Przed dokonaniem tego aktu przybrano Matkę Boską w pozłacaną chustę i suknię. Głowa Madonny w chuście jest pochylona nieco w prawo, oczy mało widoczne spod spuszczonych powiek, usta małe, lecz o silnym wykroju. Twarz Madonny ma coś w sobie z rafaelowskiego wdzięku, jednak wyraża jakąś mistyczną ekstazę. Pod szyją mały dekolt i suknia bogato udrapowana. Dłonie o długich palcach złożone jak w akcie pokory. Na ramionach narzucony płaszcz. Kolory szat są zgodne z przepisami liturgicznymi i, mimo wieków, nic prawie nie zatraciły ze swej intensywności. Dodać tu jeszcze można, że Matka Boska bardzo przypomina swoją kompozycją „Mater Amabilis”, jeden z cenniejszych obrazów Sassoferrato.

Pod obrazem czytamy dzisiaj napis: „Consolatrix afflictorum”, tzn. Pocieszycielka Strapionych. Na drzwiczkach wiodących poza ołtarz są podobizny polskich świętych, a mianowicie św. Jana Kantego i św. Kazimierza.

Na prawej ścianie prezbiterium wmurowano pamiątkową tablicę, nadzwyczaj skromną, z następującym napisem: 


\section{D.O.M.}

Memoriae Antoni Śliwiński rectoris

decoratique huius ecclesiae per annos 40 .

Natus A.D. 1820 , ordinatus 1845 , obiit penes

hanc ecclesiam die 24 August. A. D. 1894

W obrębie prezbiterium zwracają jeszcze uwagę dwa duże obrazy, z których jeden przedstawia św. Katarzynę Sieneńską, a drugi - św. Andrzeja Apostoła.

Ambona malowana jest na biało, lecz krawędzie ma złocone. Na jej ścianach są namalowane wizerunki czterech ewangelistów z symbolami. Dekoracją baldachimu ambony jest postać św. Augustyna, patrona zakonu. Linią swego ciała przypomina on rzeźbę barokową.

W nawie kościoła wznoszą się cztery ołtarze. Po stronie południowej pierwszy od prezbiterium to ołtarz św. Mikołaja. W dolnej kondygnacji tego ołtarza jest cokól kamienny, ozdobiony po bokach dwiema parami małych pilastrów. Na pilastrach ornament, który przypomina rozetę ze stylizowanych liści akantu. U dołu i u góry cokoły zamykają się gzymsami. Na dolnym gzymsie drobne listki akantowe. Nad pilastrami kamienne kolumny w stylu jońskim, nieco zromanizowanym. Ponad głowicami tych kolumn biegnie znowu gzyms z wolimi ślepiami. Na gzymsie ustawił budowniczy ołtarza dwa przyczółki w kompozycji symetrycznej. Tuż pod łukiem gzymsowym niszy wmurowane zostało oko Opatrzności Bożej. Jedyną ozdobą przyczółków tego ołtarzta jest ornament winnego grona. Na przyczółkach lekko przysiadły cztery postacie aniołków. Między kolumnami stoją figury kamienne, przedstawiające św. Piotra i św. Pawła.

Po przeciwległej stronie nawy stoi ołtarz św. Tekli, wykonany z drewna, malowany na marmur. Z każdej strony obrazu wznoszą się po dwie kolumny, na których spoczywa architraw z dekoracją kwiatową. Obraz św. Tekli należy również do cenniejszych dzieł w kościele św. Ducha. Święta ma na lekko pochylonej w prawo głowie diadem z pereł i złota. Dwie wiązki pereł zwisają na jej szyi. Suknia dwuczęściowa z dekoltem, z rękawami do połowy przedramienia. Górna jej część jest w kolorze szafirowym i sięga do kolan, dołem obramowana, rękawy zakończone są koronką. Dolna część, czyli spódnica, dotyka ziemi. Święta Tekla ma również na sobie obcisły gorset ze złotogłowiu, pokryty haftami, przyozdobiony drogimi kamieniami. Poza tym widzimy u niej w prawej ręce krucyfiks, a w lewej palmę męczeństwa. Obok jej stóp spoczywają lew, wół i węże, a oprócz tego dopala się stos drewna. Poza plecami świętej zarysowują się mury obronne na tle ciemnego i chmurnego krajobrazu. Wokół głowy świętej chmury nabrały złocistego blasku, w obłokach unoszą się postacie aniołków - z wieńcem dla męczennicy. Do lewego ramienia św. Tekli przyczepiony został purpurowy płaszcz, który opadając tworzy tło dla wydatnej kibici. Obraz powstał w czasach późnego baroku i niektóre cechy tego dzieła nie- 
znanego artysty w wyraźny sposób wskazują na to, jak np. krzywa linia postaci i pełne kształty ciała.

Pozostałe dwa ołtarze w nawie swoją strukturą podobne są do ołtarza św. Tekli. W jednym z nich zawieszony jest obraz św. Antoniego, a w drugim stoi rzeźba Pana Jezusa - Ecce Homo. Na wszystkich ołtarzach kościoła św. Ducha pozostawił swe piętno styl klasycystyczny.

Do zasługujących na uwagę obrazów należy jeszcze tutaj portret przeora wielkoksiąskiego klasztoru Kaspra Wojciecha Aurelego Mysłowskiego, wykonany w 1835 r. przez artystę malarza Lipowskiego z Krakowa.

W r. 1864 przestaje istnieć zarówno klasztor ksiąski, jak i wiele innych.Bezpośrednią przyczynę likwidacji klasztorów dało oczywiście powstanie styczniowe. W myśl rozporządzenia carskiego, skazane na likwidację klasztory dnia 27 października 1864 r., o godzinie 8 wieczorem, obstawiono wojskiem. Po dokonaniu tego odczytano zebranym w refektarzu zakonnikom ,ukaz” carski, a następnie wywieziono ich w kibitkach do klasztorów etatowych. Większość zakonników z Książa musiała udać się do Wielunia. Majątek klasztorny został skonfliskowany, a następnie rozdany pomiędzy wysłużonych wojskowych $\mathrm{z}$ armii carskiej (!).

Po kasecie klasztoru, z całego konwentu jedynie ks. Antoni Franciszek Śliwiński pozostał w Książu Wielkim. Był on ostatnim przedstawicielem zakonu św. Augustyna na terenie naszego miasta. Wraz z jego śmiercią w 1894 r. zakończył się tutaj pobyt augustianów, który trwał ponad pięć wieków. W 1899 r. przybył do Książa Michał Sławeta, kandydat św. teologii, i osiadł przy kościele poaugustiańskim jako jego rektor. Gdy zmarł, kościół św. Ducha oraz budynek klasztorny przeszly pod kuratelę miejscowego proboszcza.

\section{CMENTARZ I DZWONNICA}

We wschodniej stronie cmentarza stoi obecnie krzyż żelazny, na podstawie kamiennej. Do 1914 r. znajdował się on na Rynku, tuż przy bramie kościoła parafialnego. Wówczas była przy nim tablica żelazna, upamiętniająca uwłaszczenie chłopów.

Po wielkim pożarze, jaki nawiedził klasztor w r. 1741, spłonęła drewniana dzwonnica. W dwa lata później, w r. 1743, w zachodniej części cmentarza wystawiono nową dzwonnicę, również z drewna, pokrytą gontem. Na jej szczycie zatknięty był krzyż żelazny. Nie doczekawszy stu lat zgorzała ona znowu wraz $\mathrm{z}$ kościołem i klasztorem w $1836 \mathrm{r}$. Następną dzwonnicę wymurowano już z cegły, w kształcie złamanego łuku (neogotycka) zwieńczonego krzyżem żelaznym. Na cięciwie zawieszone zostały dwa niewielkie dzwony. Na większym z nich (o rozpiętności $40 \mathrm{~cm}$ ) biegł napis następującej treści: „1901 ad hon(orem) B(eatae) M(ariae) V(irginis) rectore eccl(esi)ae Mich(ael) Sławe- 
ta” (1901, na cześć Najśw. Panny Marii, za rektoratu Michała Sławety). Obydwa dzwony zostały wywiezione przez okupanta niemieckiego 30 września $1941 \mathrm{r}$.
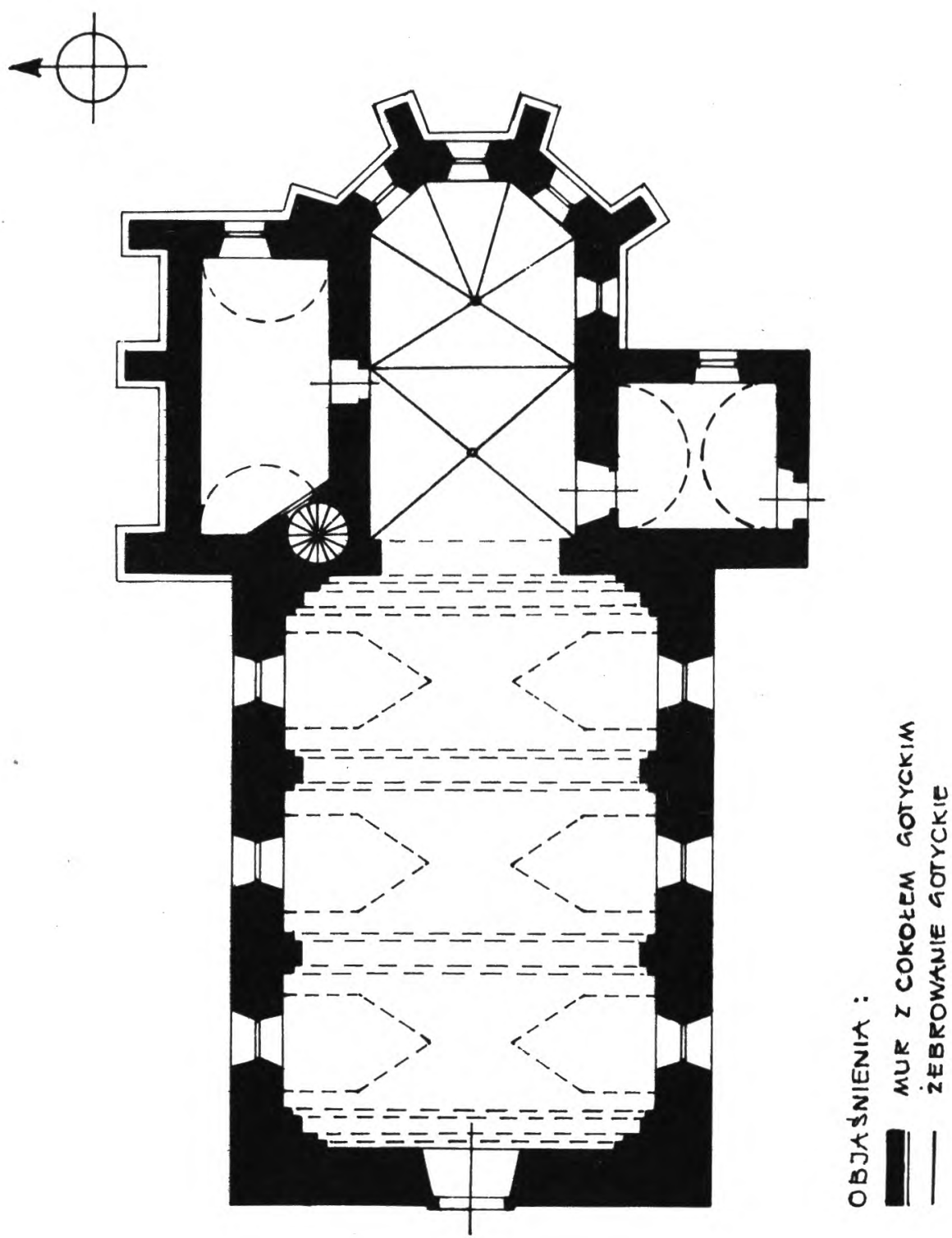

2. Plan kościoła św. Ducha w Książu Wielkim, wykonany w r. 1979 przez E. Madejskiego na podstawie rysunku z Kroniki parafialnej ks. G. Augustynika. 


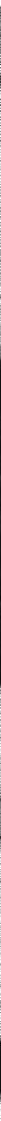

3. Plan klasztoru Augustianów w Książu Wielkim, wykonany w roku 1866 przez Alfonsa Welkego (AGAD). 


\section{APARATY KOŚCIELNE}

Jan Długosz pisał pierwszy w Liber beneficiorum, że Melsztyński, kasztelan krakowski, nie tylko zbudowal kościół augustianom w Książu Wielkim, lecz również wyposażył go w kielichy, krzyże, ornaty, księgi i tablice. W czasach późniejszych miejscowy konwent już się nie zetknął z tak szczodrą ręką dziedziców miasta, jaką miał Jan z Melsztyna. Ponadto zaś w okresie reformacji, na tle różnicy wyznań, doszło nawet do usunięcia stąd augustianów przez dziedzica Książa, kalwina Jana Bonera. Jego łupem stały się wtedy nie tylko ich grunty, ląki i ogrody, lecz również i kosztowności kościelne.

Po powrocie do Książa Wielkiego augustianie musieli od nowa kompletować dla swojego kościoła różnego rodzaju aparaty liturgiczne. Miejscem ich przechowywania przy kościele św. Ducha była najpierw stara zakrystia, w której oknie osadzono grubą kratę, a drzwi zabezpieczono okuciem żelaznym. Gdy w r. 1783 archidiakon Kochański inwentaryzował srebra liturgiczne u miejscowych augustianów, wówczas był tym zaskoczony, że w ich kościele znajdowała się tak „,szczupła argenteria”. Składała się ona w tym czasie ze starej monstrancji srebrnej, jednej puszki i czterech kielichów. Ten zestaw zmniejszył się o dwa kielichy za pierwszej kadencji przeora Paszkowskiego (1801 - 1803) i taki już pozostał bez zmian do chwili obecnej.

Najstarszym zabytkiem sztuki złotniczej, jaki się dochował do naszych czasów w kościele św. Ducha, jest srebrna puszka, złocona, o której już wyżej wspomniano. Wraz z nakrywką ma ona $26 \mathrm{~cm}$ wysokości, szerokość czarki $8,5 \mathrm{~cm}$, szerokość podstawki $-9 \mathrm{~cm}$. Dolna część przykrywki, nodus i cokolik stopki są ozdobione techniką trybowania. Głównym motywem dekoracyjnym na nodusie i stopce jest ornament okuciowy. Na czarce wykonał złotnik przy pomocy rylca herb margrabiów z Mirowa Gonzagów Myszkowskich. Nad tarczą herbową dał zaś koronę margrabiowską, a obok niej inicjały S[tanisław] M[yszkowski]. To godło z literami miało uwiecznić ofiarodawcę puszki, którym był Stanisław Myszkowski, dziedzic Książa Wielkiego, szósty ordynat (w latach 1669 - 1684). Nie ulega więc wątpliwości, że ten zabytek sakralny dostał się miejscowym augustianom w tym czasie, gdy wielkoksiąskie dobra były w jego ręku.

Tylko jeden z dwóch kielichów, które dotrwały do obecnej chwili przy kościele św. Ducha, posiada dla nas większą wartość. Jest on wykonany z mosiądzu i złocony. Jego wysokość ma $22 \mathrm{~cm}$, a średnica podstawki $12,5 \mathrm{~cm}$. Jest na nim wyryty r. 1762 i cztery inicjaly: M.Z.A.T., trudne dziś do rozwiązania. W przeciwieństwie do gładkiej w całości czarki, pozostałe części kielicha różnią się dekoracją trybowaną.

Kościół poaugustiański w Książu Wielkim, podobnie jak dawniej tak i teraz, dysponuje tylko jedną monstrancją. Jest ona darem Pauliny z Potockich Wielopolskiej, żony słynnego Aleksandra. Na jej kupno w $1841 \mathrm{r}$. podarowała 
500 zł. Ten dar dziedziczki Książa Wielkiego został wykonany z blachy mosiężnej, którą następnie pokryto złotem wyłączywszy dekorację z promieni pokrytą srebrem. Wysokość monstracji wynosi $75 \mathrm{~cm}$, rozpiętość promieni-31,5 x $35 \mathrm{~cm}$, a średnice podstawy -20 i $26 \mathrm{~cm}$. Przegub podstawy zdobi dość szeroki ornament ze stylizowanych kwiatów. Wokół słońca biegną dwie warstwy promieni, z których szersza ozdobiona jest winoroślą. Górne promienie monstrancji przysłaniają obłoczki z popiersiem Boga Ojca, a dolne - promienista aureola $\mathrm{z}$ Duchem Świętym.

Z zachowanych szat liturgicznych jedynie niektóre ornaty posiadają znaczną wartość artystyczną i zabytkową. Wielka tylko szkoda, że na temat ich przeszłości nie można wiele powiedzieć.

Starszymi ornatami zaopiekował się troskliwie ks. Augustynik. Jego zasługą jest, że stare i pięknie haftowane części ornatów w postaci słupów i aplikacji znalazły się na nowym tle. O jednym z nich wspomina ks. Augustynik w kronice parafialnej, że pochodzi z czasów króla Batorego, lecz bliżej nie określił, o jaki ornat chodzi. Pochodzenie zaś innych starych części ornatów można bez większych zastrzeżeń odnieść do wieku XVII i XVIII.

$\mathrm{Na}$ szczególne wyróżnienie zasługuje ornat, przypuszczalnie z 1 . połowy XVIII stulecia. Na białym tle atłasowym biegnie haft o symetrycznym układzie, przedstawiający stylizowane liście i kwiaty. Motyw kwiatowy nie jest zbytnio przeładowany. W innym zachowanym ornacie czerwonym słup jego tkany jest ze srebra, przybrany został kwiatami, boki zaś stylizowanymi różami, bławatkami i kielichami dzwonków. Nowe podbicie do niego fundowała margrabina Wielopolska. Wreszcie ornat fioletowy ma podbicie z aksamitu. Gruby haft ze srebrnych nici tworzy trzy pary palmet.

\section{PRZEORZY KONWENTU W KSIĄŻU WIELKIM}

Upłynęło bez mała dwadzieścia lat od momentu wprowadzenia augustianów do Książa Wielkiego, zanim pojawiło się w dokumentach imię jednego z pierwszych przeorów miejscowego zgromadzenia braci pustelników św. Augustyna. Tym przeorem, o którym będziemy tutaj mogli najpierw mówić, był S t e f a n, notowany na przestrzeni lat $1400-1411$ w aktach rady miasta Kazimierza i krakowskich sądów ziemskich. Następnie w wykazie tutejszych przeorów znajduje się olbrzymia przerwa, która trwała przez 135 lat, czyli do r. 1546. Mogło być wiele powodów jej powstania, ale w obecnej chwili trudno jest dociekać przyczyny tego faktu.

Kolejnym przeorem, którego imię widnieje w aktach, był Stanisław. Podpis jego znajduje się na prośbie z r. 1546, jaką przełożeni klasztorów św. Augustyna w Polsce przesłali do swego generała, ażeby ich oddzielił od prowincji bawarskiej, gdyż związek taki ujemnie wpływa na ich pracę. W takiej 
postawie podpisanych przejawił się zapewne odruch patriotyzmu oraz próba hamowania nowinek religijnych z Niemiec.

Następny - Mar cin - pojawil się 15 marca 1555 r. w aktach oficjała krakowskiego w sprawie zaległych dla klasztoru czynszów.

Dalej dopiero Maciej Karski. W archiwaliach związane są z jego osobą dwie daty: 14 styczeń 1599 r. i 12 wrzesień 1602 r. Pierwsza z nich dotyczy wniesienia do ziemskich ksiąg sądowych w formie oblaty odpisu aktu fundacyjnego, który wystawił augustianom Spytek z Melsztyna. Po raz drugi zaś utrwalił się przeor Karski w księdze wójtowskiej Książa Wielkiego, gdy przed sądem miejskim dochodził swych racji o pieniądze.

Feliks J a s kłow s ki, 15 lutego 1606 r. otrzymał w imieniu konwentu św. Ducha z Książa Wielkiego darowiznę we wsi Jasionnie (Jędrzejowskie).

Marek Słupski, od 27 kwietnia do 22 czerwca 1611 r. procesował się z Adamem Bonerem, dziedzicem Mianocic, o zwrot gruntów klasztornych na Brzezinkach i Podbrzeziu.

Ferdynand Lipold, $1614 \mathrm{r}$.

Adam N a r y m s ki, 26 maja 1618 r. objął przeorstwo w Książu Wielkim, które opuścił w $1621 \mathrm{r}$.

Walenty Ni e s zo w in a, 20 lipca 1637 r. zmarł w Książu jako przeor tutejszego konwentu.

Hiacynt Kras nostaws ki, 20 kwietnia 1643 r. zmarł również tutaj, pełniąc funkcję przeora.

Marcin B u l e wi cz, doktor teologii, przeor wielkoksiąskiego konwentu od 1664 do 1667 r. Dużą popularność zdobył sobie znajomością kilku języków obcych (hiszpański, włoski i francuski). Po opuszczeniu konwentu ksiąskiego był również przeorem w Zaturcach i Lublinie. Podobno zmarł w Brześciu nad Bugiem.

Tomasz Krog u ls ki, dnia 29 grudnia 1666 r., w jego obecności, notariusz sądu grodzkiego w Krakowie dokonal wpisu testamentu Anny Mohylanki, której mężem był dziedzic Książa Wielkiego margrabia z Gonzagów Myszkowski. W tym dokumencie przeznaczyła ona czynsz dla miejscowych augustianów. Krogulski zmarł w Warszawie 18 sierpnia 1698 r.

Marceli Brzezińs ki, 23 kwietnia 1668 r. zakończył swój żywot w tutejszym konwencie jako jego przeor.

Michał Wi e cz orki e wi cz, przeor konwentu, w Książu w 1669 r. Poprzednio był przeorem orchowieckim.

Patrycy R y man owski, doktor teologii, przeor. Zmarł w 1673 r.

Józef J a nicki, przeor konwetu, zmarł w 1684 r.

Franciszek Starowiej ski. Pełnił funkcję przeora od 1 czerwca 1688 do 24 maja 1691 r. Za jego kadencji Tomasz Bielecki, dziekan jędrzejowski, z pobudek religijnych zapisał augustianom w Książu 70 florenów polskich czynszu od kwoty $1000 \mathrm{zl}$. 
Ludwik Muchowi e cki, herbu Pobóg, pochodził z bełskiej lub ciechanowskiej ziemi. Przez jakiś czas piastował godność przeora w Książu Wielkim, jednak z niewiadomych powodów zrzekł się tej funkcji. Podobno w kilka lat po tej rezygnacji umarł tutaj 30 maja $1697 \mathrm{r}$.

Anzelm Zielińs ki 6 października 1698 r. wystąpił po raz pierwszy jako przeor miejscowego konwentu, gdy ten w krakowskim sądzie grodzkim otrzymał folwark na Glowianach. Jeszcze w roli przeora był w pobliskim Kozłowie 1 listopada 1718 r. Zmarł w Książu Wielkim 22 kwietnia 1724 r.

Epifaniusz G ą si o r ow s ki, któremu dnia 10 lipca 1700 r. kapituła zakonna w Olkuszu powierzyła funkcję przeora w Książu Wielkim. W trzy lata później na to samo stanowisko wyznaczyła go kapituła augustianów w Krasnymstawie i jednocześnie zaleciła mu, ażeby zajął się odbudową zniszczonego przez nieprzyjaciół zespołu zabudowań klasztornych. Jego kadencję w miejscowym konwencie przedłużyła jeszcze 27 kwietnia 1706 r. kapituła w Zaturcach. Na dacie 1 listopada 1708 r. urywają się ślady pobytu przeora Gąsiorowskiego w Książu Wielkim.

Michał Głu chowski, przeor (?), zmarł w 1709 r.

Konstanty Mucharski, herbu Gozdawa. 13 maja 1710 r. na posiedzeniu kapituły w Krasnymstawie występowal jako przeor wielkoksiąski. W tej samej roli jest tutaj Mucharski jeszcze w latach 1734 i 1735 (zob. niżej).

Symplicjan Karkutowski, lektor teologii, przeorem wybrany 10 maja 1713 r. na kapitule warszawskiej.

Rafał Niklaus, doktor teologii, przeor konwentu od 12 października 1714 do 14 lipca 1718 r. Najpierw wyznaczono go do Książa jako przeora wikariusza na zastępstwo chorego przeora Karkutowskiego i w tej funkcji występuje 9 lipca 1713 r. Gdy przeor Karkutowski wyzdrowiał i opuścił klasztor wielkoksiąski, wówczas faktycznym przeorem został Niklaus. Następnie, po czteroletniej rezydencji, o. Rafał przeniesiony został do Olkusza. Po kilku latach chętnie wrócił do miejscowego klasztoru, ale poświęcił się tutaj kaznodziejstwu i pracy naukowej. Jego dorobek twórczy ukazał się drukiem już w 1697 r. Dochowane zapiski parafialne są ponadto dowodem, że nadal tytułowano go przeorem, chociaż godności tej potem już nie piastował. Zmarł w Książu Wielkim 30 października $1730 \mathrm{r}$.

Emeryk Ostrowski, przeor konwentu od 4 lipca 1718 do września 1719 r. Do Książa przyjechał na wizytację prowincjał, ażeby przyspieszyć odbudowę kościoła klasztornego, która, jego zdaniem, posuwała się opieszale. Na jego wniosek kapituła wszystkimi głosami wybrała na przeora w Książu Wielkim Emeryka Ostrowskiego, który miał być o wiele aktywniejszym w ukończeniu „fabryki” kościoła. Ostrowski jednak już po kilkunastu miesiącach zrezygnował z przeorstwa i opuścił miejscowy konwent.

Teodor J a r e c ki vel J a r o c ki, lektor teologii, przeor od września 1719 do listopada $1721 \mathrm{r}$. Z powodu choroby musiał z przeorstwa ustąpić. 
Wawrzyniec Jan Cze pańs ki, doktor św. teologii, przeor konwentu od listopada 1721 do września 1722 r. Urodził się w 1659 r. na Kazimierzu w Krakowie. Był synem Wojciecha (narodowości węgierskiej) i Elżbiety. Ze swoim bratem Dominikiem wyjechał do Rzymu, aby tam studiować filozofię i teologię. Wawrzyniec złożył śluby zakonne 15 sierpnia 1675 r. Gdy wrócił do ojczyzny, był lektorem i profesorem teologii. Pełnił też funkcję przeora w Wieluniu, Olkuszu i dwukrotnie w Krakowie. W latach 1713 - 1715 zajmowal stanowisko prowincjała. W r. 1697 wydano drukiem jego utwory napisane po lacinie. Jego pobyt w Książu był krótki, ponieważ okazało się, że był dobrym teologiem i kaznodzieją, ale brakowało mu kwalifikacji budowniczego, a przy tym może i zdrowia. Z Książa wyjechał do Krakowa i tam wkrótce zmarł 28 sierpnia 1724 r.

Franciszek Si ci ń s k i był przeorem od września 1722 r. do dnia swej śmierci 23 maja $1724 \mathrm{r}$.

Chryzostom U la to w s k i objął stanowisko przeora w $1725 \mathrm{r}$.

Dominik Trybuls k i został przeorem w Książu Wielkim 29 września 1728 roku.

Alfons Kwán niews ki był przeorem augustianów od 1731 r. do 10 stycznia 1733 r. Przy miejscowym konwencie zakończył swój żywot.

Konstatny Mucharski był, powtórnie, przeorem w latach 1734 - 1735. Opuścił miejscowy klasztor na własną prośbę, lecz potem znowu się tutaj zjawił i był zastępcą przeora.

Pontian B a c z y ń s ki. W czasie kontroli wielkoksiąskiego konwentu jemu powierzył wizytator funkcję przeora miejscowych augustianów.

Ambroży Rogoziński w roli przeora z Książa Wielkiego bierze udział w obradach kapituły, które odbyły się w Zaturcach w r. 1737 (zob. niżej).

Karol Zajączkowski. W latach $1737-1740$ był przeorem konwentu wielkoksiąskiego.

Klemens Penquit t pełnił funkcję przeora od 1740 r. do września $1743 \mathrm{r}$.

Tomasz Wóycikiewicz, bakałarz teologii. Pochodził z Nowej Wsi. Dnia 28 września 1743 r. „otrzymał” on tutejszy konwent na kapitule w Lublinie. Przybył do Książa z kłasztoru krakowskiego. Wyjechał zaś z końcem września $1746 \mathrm{r}$.

Mateusz B aleszyński. Na stanowisku przeora od 14 października 1746 r. do 24 kwietnia 1748 r. Zanim został przeorem, był tu przez kilka lat kaznodzieją.

Gwilhelm Kozłowski, bakałarz teologii, przeor od 24 kwietnia 1748 do 30 września $1752 \mathrm{r}$.

Łukasz Kopczy ńs ki, przeor konwentu od września 1752 r. do 14 kwietnia 1754 r. Umarł w Książu Wielkim.

Jan Nepomucen Models ki, przeor augustianów od 1 listopada 1752 r. do 11 sierpnia $1756 \mathrm{r}$. 
Aureli Barańs ki, przeor konwentu od 13 sierpnia 1756 r. do 30 grudnia 1759 r.

Ambroży Rogozińs ki powtórnie rezyduje w Książu od stycznia 1759 r., jednak piastowanie godności ksiąskiego przeora przerywa śmierć w marcu $1760 \mathrm{r}$.

Norbert Pruske zjawił się tutaj na stanowisku przeora w pierwszych dniach kwietnia 1760 r., po raz ostatni zaś wspominają go miejscowe archiwalia kościelne 26 czerwca 1765 r. Z Książa wyjechał na wiceprzeorstwo do Wilna, poza tym jakiś czas był też przeorem w Warszawie. Umarł 20 maja 1787 r.

Augustyn St ankiewicz, bakałarz św. teologii. W r. 1765 na odbywającym się w Krasnymstawie posiedzeniu kapituły otrzymał przeorstwo ksiąskie. Ponieważ rozchorował się tutaj umysłowo, wikariuszem przeorem mianowano Stanisława Bayera (1769).

Walery B o r ow s ki, przeor konwentu od września 1769 r. do czerwca 1773 r. Po opuszczeniu Książa był przeorem w Wieluniu, a następnie w Orchówku (11 października 1811).

Benedykt J e ch eł k a. Już w maju 1759 r. mówią miejscowe akta kościelne o jego pobycie w ksiąskim konwencie. Na kapitule warszawskiej w czerwcu 1773 r. mianowano go przeorem tutejszego klasztoru. W sześć lat później zrzeka się tego tytułu, jednak Książa nie opuszcza pozostając nadal w roli kaznodziei (zob. niżej).

Marcin Pułaski. Nie wiadomo bliżej, kiedy go mianowano przełożonym augustianów ksiąskich. W czasie wizytacji 9 czerwca 1785 r. zwalnia go z tej funkcji prowincjał Erazm Bartold.

Benedykt Jechełka. Po usunięciu Pułaskiego powtórnie wybrany tutaj na przeora, jednak w sierpniu następnego roku zrzeka się tego tytułu. Od tej pory jest tylko wiceprzeorem, a owocem jego pracy na terenie miasta i okolicy było założenie bractwa św. Tekli. Umiera w Książu 11 marca 1797 r.

Henryk Faborowicz, doktor św. teologii. Na kapitule prowincji dnia 11 sierpnia 1786 r. wyznaczono go na przełożonego klasztoru w Książu Wielkim. Piastując ten tytuł przewodniczył kapitule prowincjalnej w Lublinie, 14 października $1798 \mathrm{r}$. Z nieznanych nam przyczyn zrezygnował z zajmowanego stanowiska, lecz mimo to Książa nie opuścił i tutaj też zmarł 26 maja 1807 r.

Marceli Paszkowski, doktor św. teologii. Prowincjał Konstanty Mierzwiński obdarzył go przeorstwem ksiąskiego klasztoru w dniu 16 maja 1801 r., kiedy przybył tu na wizytację. Gdy w dwa lata później była powtórna wizytacja, zyskał słowa uznania za wprowadzenie do konwentu ładu i porządku.

Gundisalwus Antosiewicz, doktor św. teologii. Ledwie 17 września 1806 r. wybrano go przeorem, a już 30 lipca 1807 r. zwolniony został za usterki w zarządzaniu klasztorem.

Gaudenty U11man, doktor św. teologii. Pochodził z Freudentalu. Sluby zakonne składał w Krakowie w r. 1781. Jako przeor rezydował w Książu po dy- 
misji Antosiewicza. W lipcu 1808 r. zastępcą Ullmana był Maksymilian Poniatowski. Przeor Ullman opuścił Książ Wielki w 1811 r., udając się do Krakowa, gdzie zmarł 16 lutego $1817 \mathrm{r}$.

Maksymilian Ponia tow s ki. Urodził się na Podlasiu w 1764 r. Przeorem ksiąskiego konwentu był od chwili wyjazdu swego poprzednika. Za jego czasów liczyło zgromadzenie miejscowych augustianów łącznie czterech .członków. Poniatowski zmarł w Książu 3 maja 1813 r. na „zgniłą gorączkę”, czyli na dur brzuszny.

Marceli Pas zk ow ski. Dnia 22 czerwca 1813 r. przybywa do miejscowego konwentu prowincjał i powtórnie przekazuje władzę nad zgromadzeniem augustianów ksiąskich Paszkowskiemu. Częste zmiany w tutejszym klasztorze, i to nie zawsze nadających się na to stanowisko osób, przyczyniły się w pewnym stopniu do upadku wielkoksiąskiej placówki zakonnej. Trzeba więc było sprężystej ręki dla jej poddźwignięcia, toteż władze zakonu augustianów przysłały tu Paszkowskiego, który swoje zdolności w tym kierunku okazał przy poprzedniej rezydencji w Książu Wielkim. Dodajmy, że w r. 1815 liczył klasztor, prócz przeora, trzech kaznodziejów (Gundisalwus Antosiewicz, Bernard Nowakowski i Andrzej Gutowski) oraz jednego kleryka (Melchior Janiszewski). Paszkowski umarł 13 sierpnia 1822 r. w Krasnymstawie.

Wojciech Dąbrowski. Dzięki udzielanym chrztom w kościele parafialnym wiemy, że rezydował tu od 11 stycznia 1820 r. do 3 lutego 1822 r.

Paweł Nokielski wystąpił tylko jeden raz w archiwaliach 5 lipca $1823 \mathrm{r}$. jako przeor konwentu.

Aureli Mysłows ki (imię świeckie Kasper), doktor św. teologii. Urodził się 3 stycznia 1781 r. Do szkół uczęszczał w Lublinie i Opolu. Do zgromadzenia wstąpił w 1807 r. i w trzy lata później otrzymał święcenia kapłańskie. Nie wiadomo bliżej, kiedy zjawił się w Książu Wielkim, aby objąć funkcję przeora. Protokół kapituły prowincji pozwala się domyślać że Mysłowski zarządzał klasztorem augustianów ksiąskich już przed 1832 r., skoro w czasie posiedzenia była mowa o powtórnym jego wyborze na to stanowisko. W tym czasie jego zastępcą był Hipolit Kałuszkiewicz, później Hiacynt Wiśniewski, a w. końcu Gwilhelm Piotrowicz. Sparaliżowany Mysłowski zmarł 6 lutego 1841 r. w Ksiąskim klasztorze.

Andrzej 'Rzadki. Dnia 20 kwietnia 1841 r. wyznaczył prowincjał Adeodat Buczkiewicz na przełożonego miejscowego konwentu Władysława Lubkowskiego, lecz prawdopodobnie ten zrezygnowal $\mathrm{z}$ powierzonej sobie funkcji. W tym jeszcze roku władzę nad klasztorem sprawował Andrzej Rzadki i prowadził odbudowę kościoła. Przypuszczalnie jednak i on uląkł się wielkiego trudu, jaki trzeba było ponosić przy restauracji budynków klasztoru, toteż po kilkunastu tygodniach (2 października) zrezygnował z Książa, składając godność przeora w ręce prowincjała.

Alipiusz Ludwik K ał użyńs ki rezydował tutaj zaledwie kilka miesięcy. 
Posydiusz R o m a n objął zarząd nad ksiąskim klasztorem w lipcu 1842 r. na polecenie prowincjała Buczkiewicza. W $1844 \mathrm{r}$. zrezygnował z tej godności, lecz w Książu przebywał jeszcze do lipca 1853 r.

Rajmund Krajewski (imiona świeckie: Karol Ludwik). Urodził się w 1841 r. w powiecie przemyskim. Po otrzymaniu święceń w 1841 r. oddał się pracy duszpasterskiej w Krakowie aż do końca następnego roku, kiedy to udał się do Książa Wielkiego, aby zostać wiceprzeorem. W r. 1841 mianowała go kapituła prowincji przełożonym tutejszych augustianów, a w rok później poleciła mu objęcie klasztoru lubelskiego. W tym czasie również otrzymał Krajewski tytuł lektora św. teologii. W hierarchii augustianów polskich doczekał się on dwukrotnego wyboru na prowincjała. Zmarł nagle w 1863 r. Jego portret można oglądać w refektarzu klasztornym przy kościele św. Katarzyny w Krakowie.

Symplicjan K ę s k i 27 czerwca 1849 r. został wybrany na przeora do Książa, lecz po trzech latach (18 października 1852 r.) zrezygnował z tej godności.

Dominik Paw ł ow s k i przybył do ksiąskiego klasztoru z Warszawy i rezydowal tutaj do lipca $1855 \mathrm{r}$.

Andrzej Rzadki mianowany został przeorem ksiąskim na kapitule warszawskiej 9 lipca $1855 \mathrm{r}$.

Mateusz Fa go ń s ki. Na kapitule, jaka odbyła się w lipcu 1857 r., chciano obdarzyć godnością przeora ksiąskiego konwentu Grzegorza Grabowskiego, jednakże ten wyboru nie przyjął. Wówczas prowincjał Rajmund Krajewski przeznaczył na to stanowisko Fagońskiego, dotychczasowego wiceprzeora w Krasnymstawie. Dokonał tego prowincjał w czasie wizytacji w Książu 22 października 1857 r. i Fagoński rezydował tutaj do kwietnia 1860 r.

Łukasz Wacław Mor a w s k i 28 kwietnia 1860 r. został przełożonym tutejszego zgromadzenia augustianów. Z powodu kasaty klasztoru 27 października 1864 r. musiał opuścić Książ Wielki i udać się do Wielunia.

Po kasacie zakonu w r. 1864 z całego konwentu w Książu Wielkim pozostał tylko Antoni Franciszek Śli w i ńs ki. Tutaj doczekał się on ostatnich dni swego żywota. Umarł na cholerę 24 sierpnia $1894 \mathrm{r}$. i pochowany został na cmentarzu grzebalnym. Antoni Śliwiński był więc ostatnim przedstawicielem zakonu św. Augustyna na terenie miasta.

W 1899 r. przybył do Książa Wielkiego ks. Michał Sł a w e ta, kandydat św. teologii, i osiadł przy kościele poaugustiańskim jako jego rektor. Poprzednio był on profesorem Seminarium Duchownego w Kielcach. Gdy umarł, kościół św. Ducha i budynek klasztorny przeszły pod kuratelę miejscowego proboszcza.

Przyglądając się tej plejadzie miejscowych przeorów można zauważyć, że w większości wypadków każdy z nich dość przelotnie traktował swój pobyt w Książu Wielkim. Znaleźli się również i tacy, którzy z miejsca oświadczali wybierającym ich kapitułom czy prowincjałom, że przeorstwa tego nie przyjmą. 
Jedynie tylko nieliczni mogli się w Książu zaklimatyzować i dokończyć tu swego żywota. Wiele czynników mogło odstręczać przeorów ksiąskich od miejscowego konwentu, ale nie jest wykluczone i to, że jednym z nich mogły być szczupłe dochody klasztoru. Poza tym małe, prowincjonalne miasteczko nie wytrzymywało konkurencji z innymi miejscowościami, w których były siedziby klasztorne augustianów.

Między ksiąskimi przeorami znajdowali się również cudzoziemcy i co do niektórych mamy pewność, że pochodzili z Niemiec. Ciekawe by było także pochodzenie społeczne rezydujących tutaj przeorów, ale brak danych przysłania te sprawy tajemnicą. Poza tym nie zawsze postawa moralna niektórych przeorów szła w parze z głoszonymi przez nich zasadami, toteż z ust wizytujących padały nieraz pod ich adresem karcące napomnienia i surowe zakazy. Również i poziom wykształcenia przeorów był różny. Znaczny ich zastęp miał jednak ukończone studia wyższe ze stopniem bakałarza, a w wielu wypadkach doktora.

\section{ŻYCIE RELIGIJNE W KSIĄŻU WIELKIM}

W swej pracy duszpasterskiej nad podniesieniem życia religijnego mieszkańców Książa Wielkiego i okolicy stosowali eremici św. Augustyna wiele środków. Jednym z nich było głoszenie kazań, do czego augustianie czuli się szczególnie powołani spośród innych zakonów. W zależności od potrzeby urządzali oni mniej lub więcej uroczyste rekolekcje dla osób świeckich i duchownych. Dla pogłębienia religijności organizowali również tutejsi zakonnicy stowarzyszenia, czyli bractwa.

W kościele katolickim występowały dawniej dwa rodzaje stowarzyszeń dla wiernych. Jedna $\mathrm{z}$ nich miała na celu akcję charytatywną (pielęgnowanie starców, chorych i wychowywanie sierot), drugie zaś podejmowały się rozbudzać żywszy kult religijny w życiu społeczeństwa. Otóż nie znajdujemy obecnie żadnych śladów w archiwaliach, czy kiedyś istniały przy klasztorze bractwa miłosierdzia, natomiast o bractwach pobożności świadczą liczne dokumenty z XVIII stulecia i z czasów późniejszych.

Najwcześniej zorganizowali augustianie ksiąscy bractwo Matki Boskiej Pocieszenia, ale kiedy zostało ono powołane do życia, tego nie można ustalić dokładnie. Pierwsza wzmianka o tym bractwie pochodzi dopiero z grudnia 1743 r. Kiedy klasztor był wizytowany przez Jacka Kochańskiego w 1783 r., to w protokóle znalazła się tylko taka notatka, że w kościele św. Ducha jest z dawnych czasów zwyczaj odprawiania nabożeństw do M.B. Pocieszenia, lecz na to nie ma żadnego przywileju ani admissy diecezjalnej. Żeby się stało zadość prawu kanonicznemu, konwent ksiąski poprosił swego generała o zezwolenie na powstanie takiego bractwa przy kościele św. Ducha. Pismo generała zakonu, 


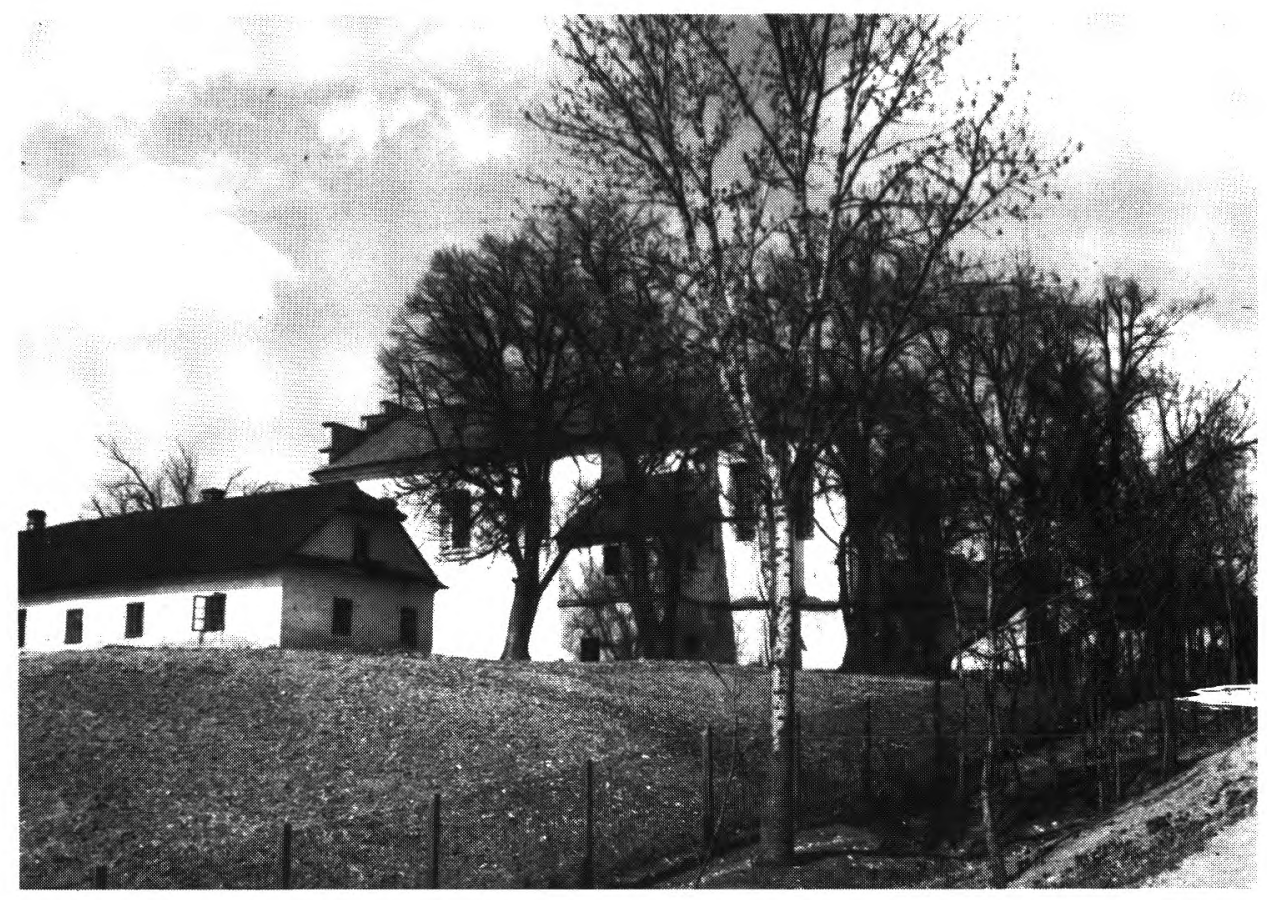

1. Książ Wielki. Kościół św. Ducha i budynek poklasztorny od strony południowo-wschodniej (fot. E. Madejski, 1968). 


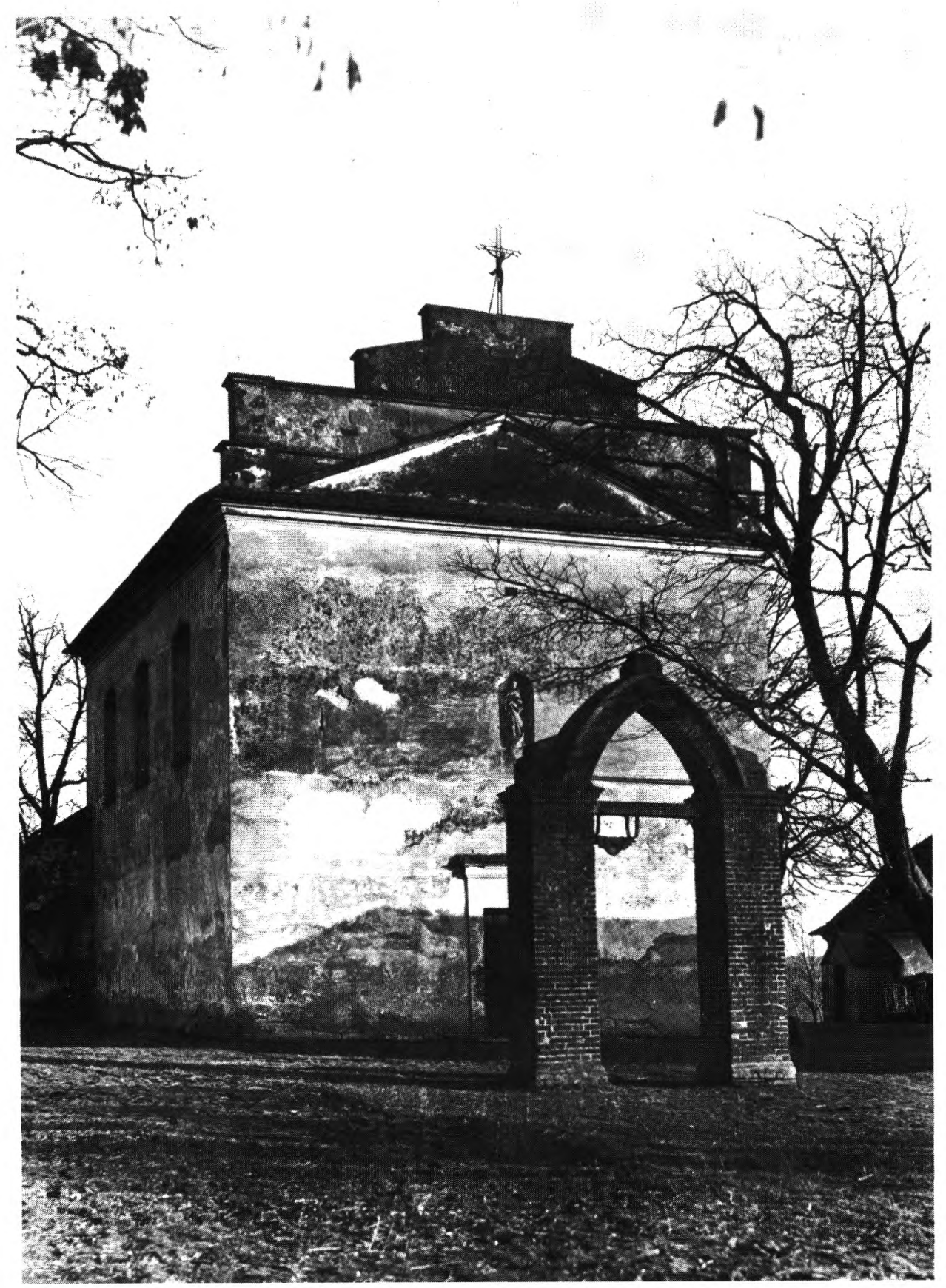

2. Książ Wielki. Zachodnia elewacja kościoła św. Ducha ze szczytem klasycystycznym z pierwszej połowy XIX wieku (for. E. Madejski, 1941). 


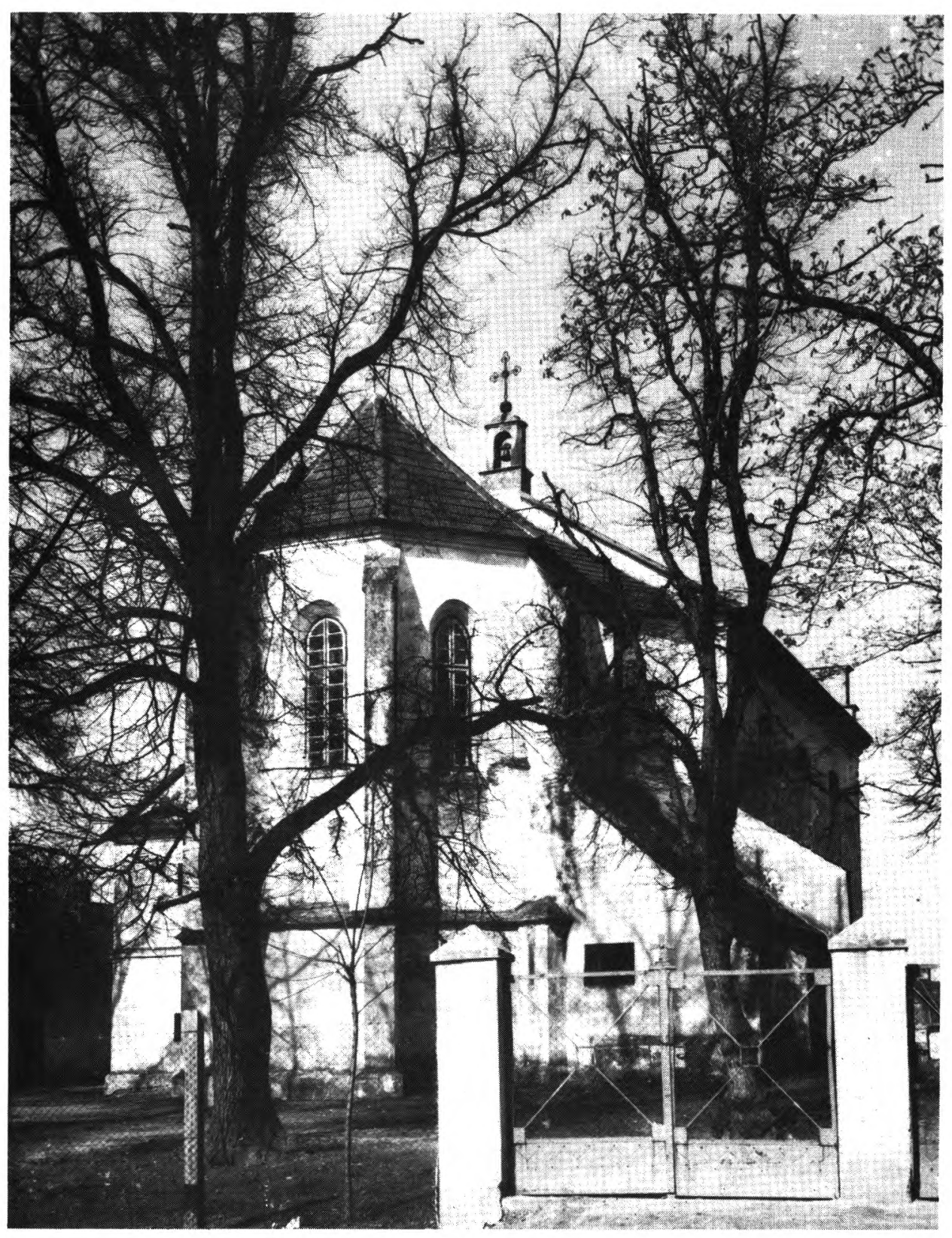

3. Książ Wielki. Gotyckie prezbiterium kościola św. Ducha (fot. E. Madejski, 1941). 


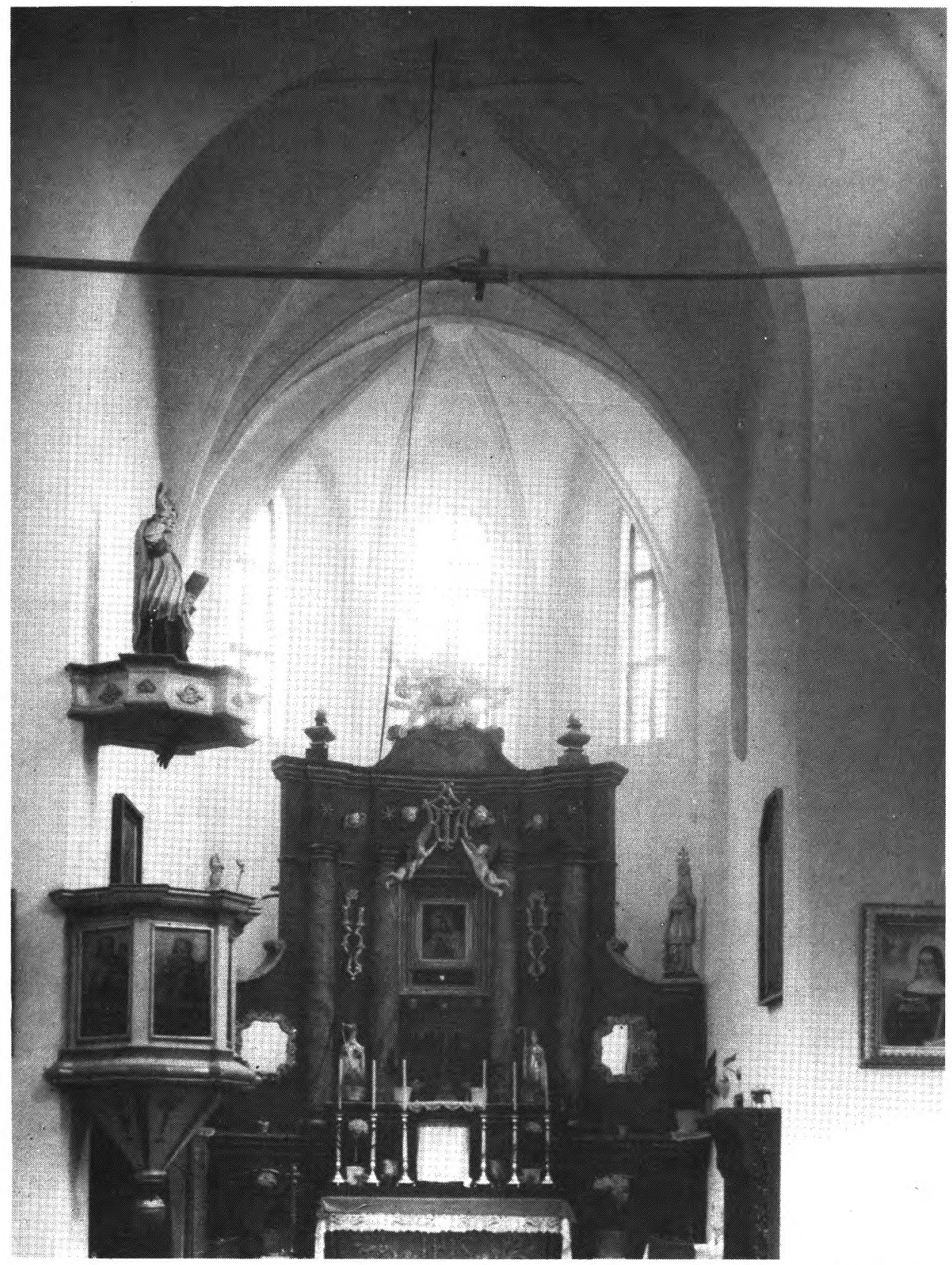

4. Książ Wielki. Ołtarz główny w kościele św. Ducha z pierwszej połowy XIX wieku (fot. E. Kozłowska, 1952; Instytut Sztuki PAN). 


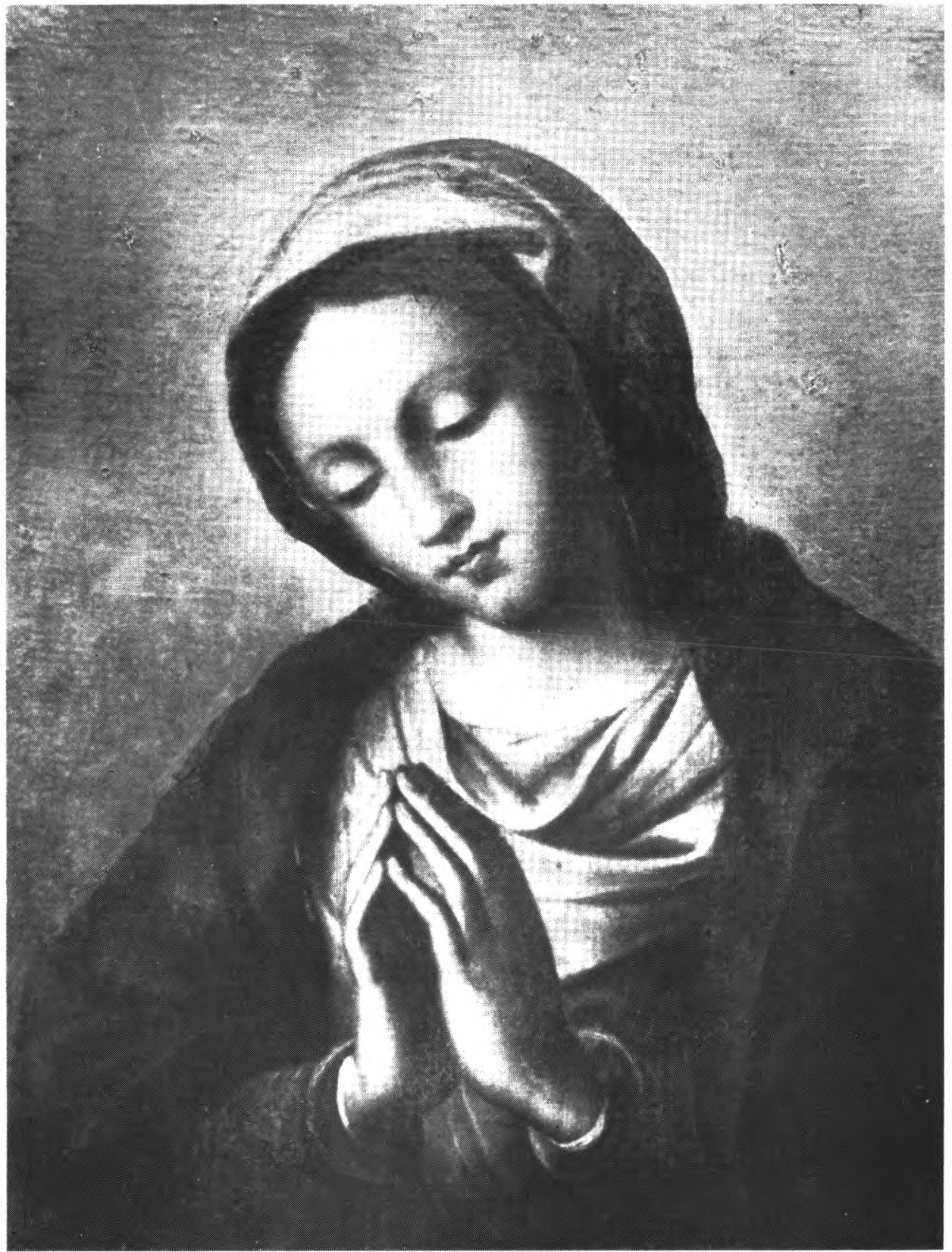

5. Książ Wielki. Obraz Madonny w ołtarzu głównym kościoła św. Ducha, dzieło G. B. Salvi-Sassoferato (fot. E. Kozłowska, 1952; Instytut Sztuki PAN) 


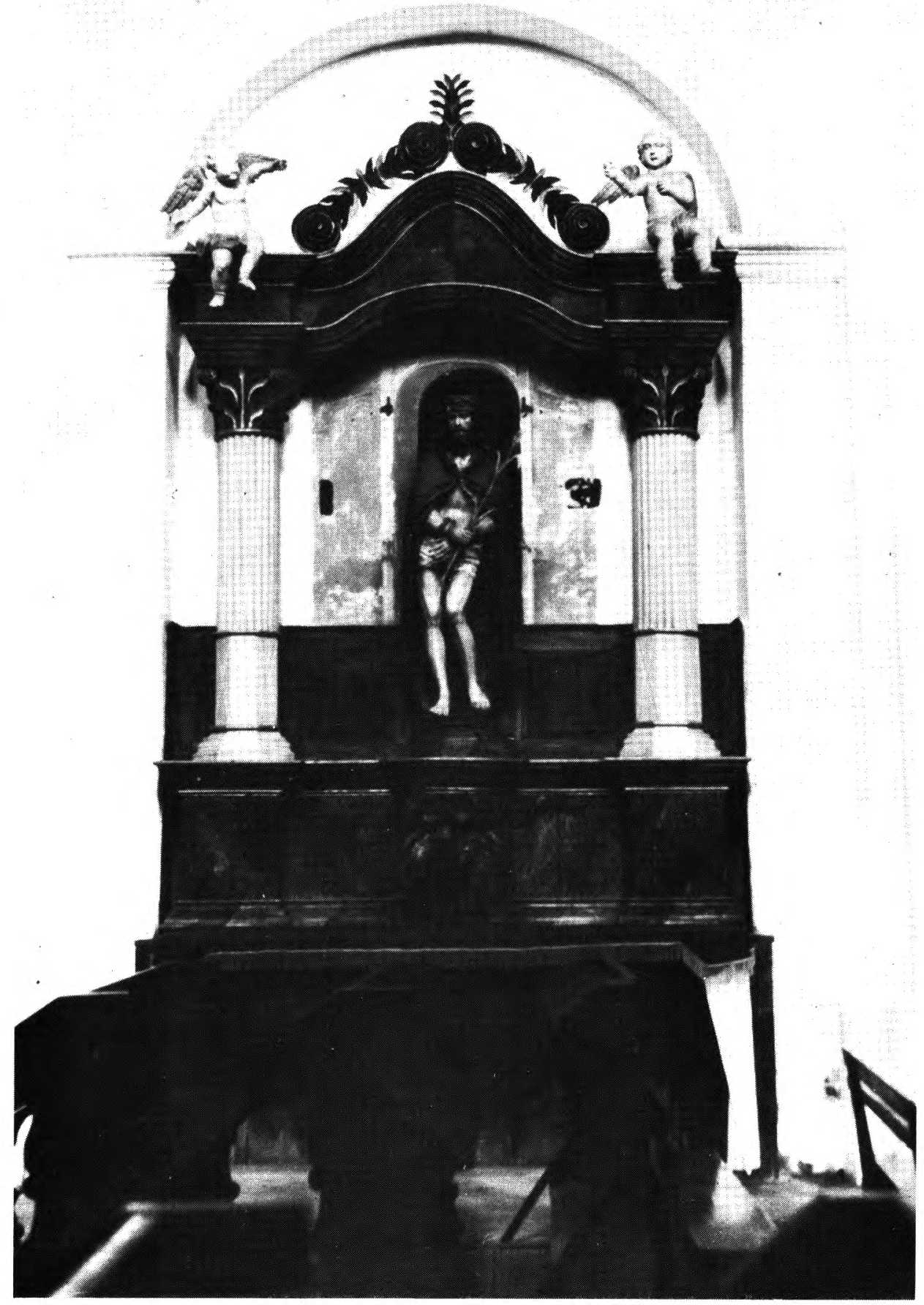

6. Książ Wielki. Ołtarz Ecce Homo z XIX wieku w kościele św. Ducha (fot. E. Madejski, 1977). 


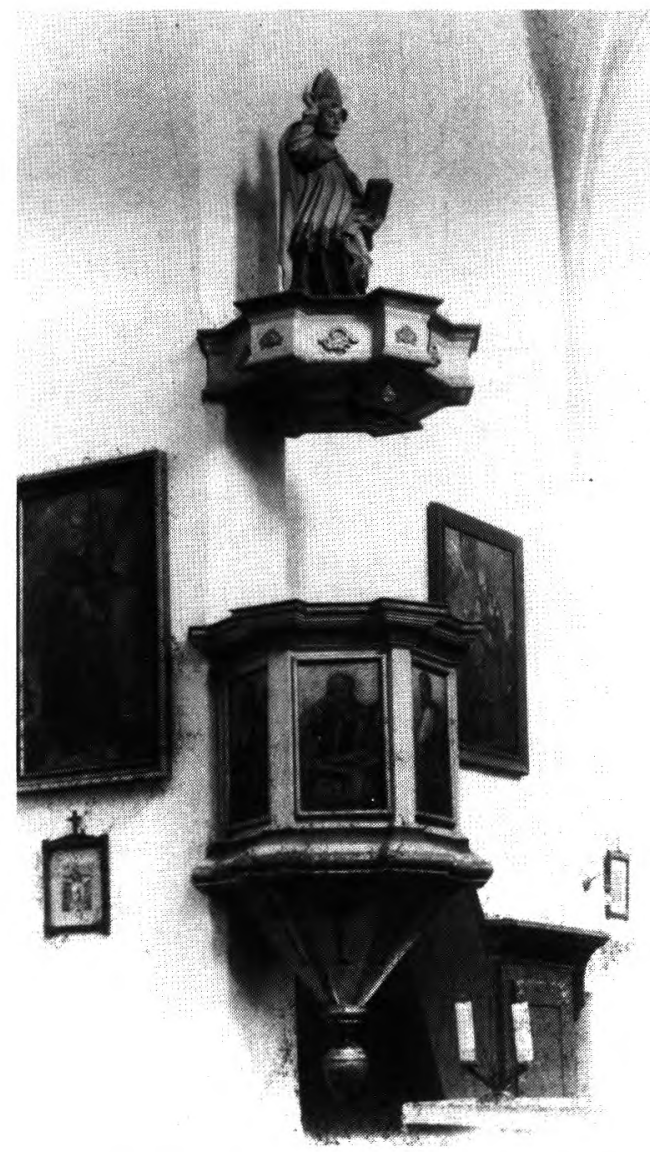

7. Książ Wielki. Ambona z pierwszej połowy XIX wieku w kościele św. Ducha (fot. E. Madejski, 1979).

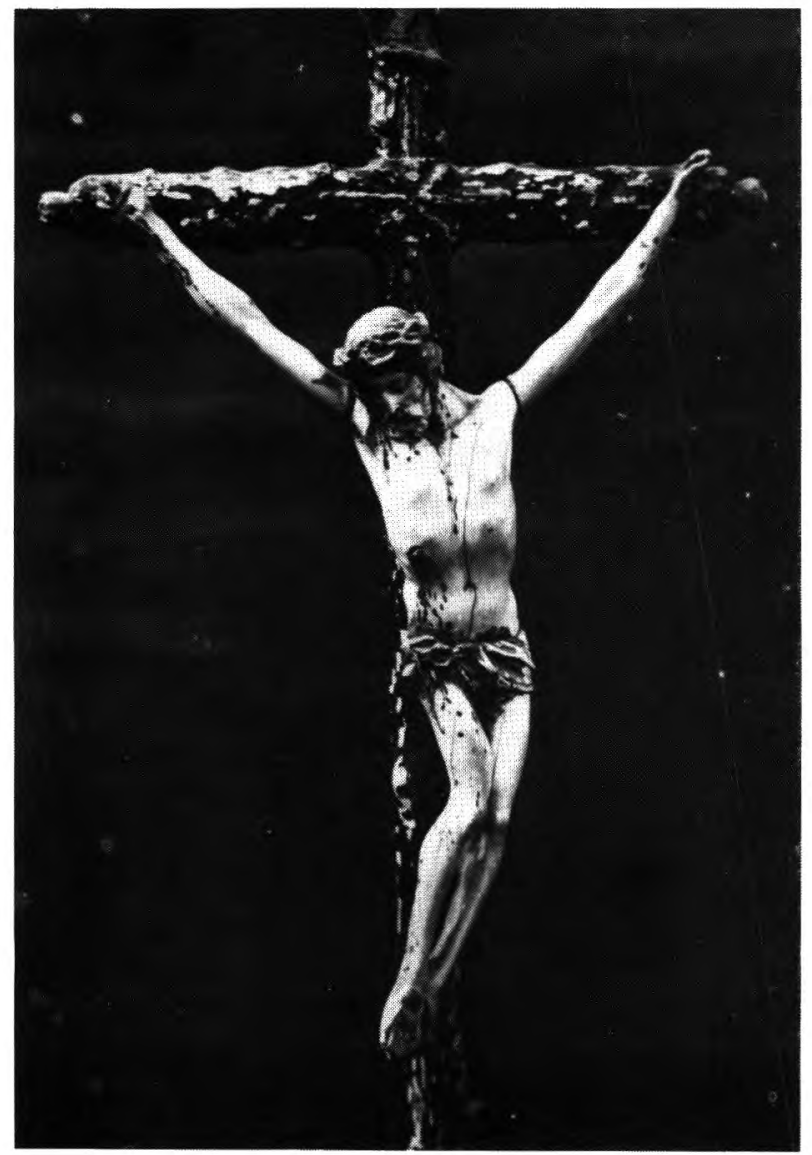

8. Książ Wielki. Krucyfiks w ołtarzu głównym kościoła św. Ducha; Chrystus z kości słoniowej z XVII w. (fot. E. Madejski, 1941). 


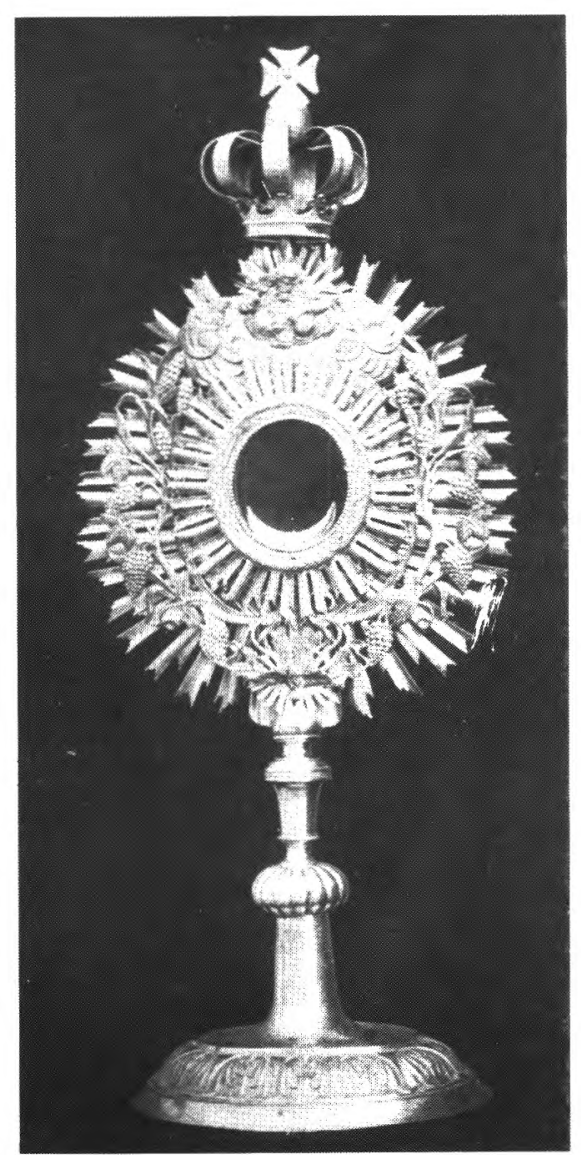

9. Książ Wielki. Monstrancja z 1841 r. (fot. E. Madejski, 1941).

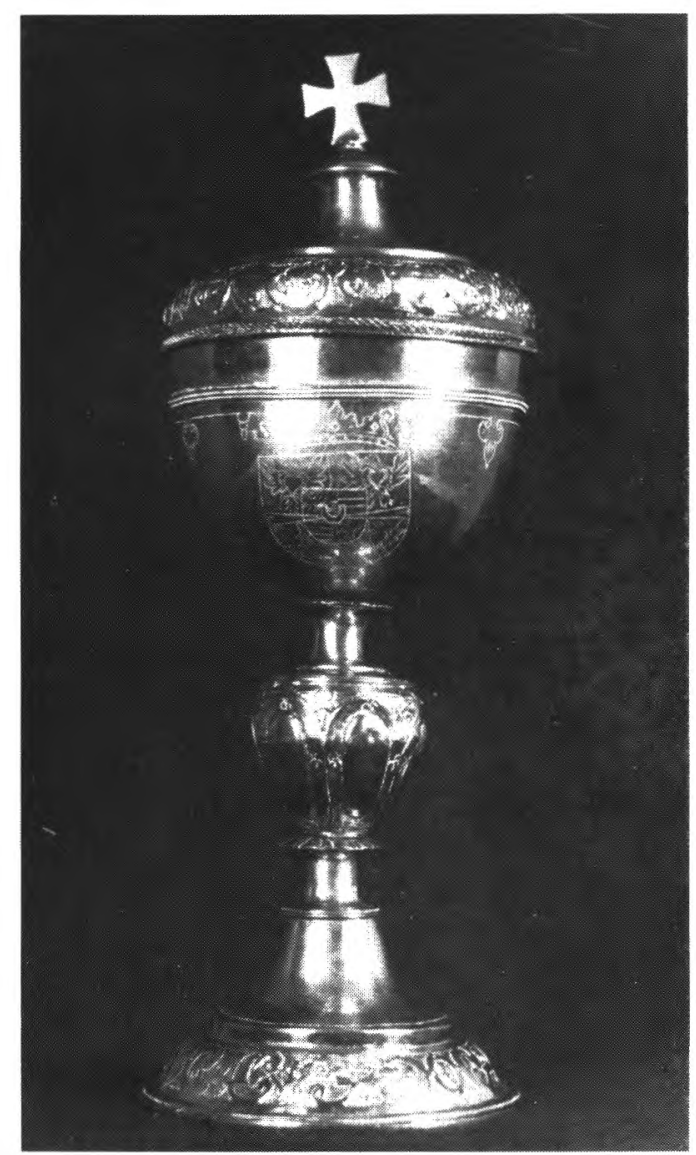

10. Książ Wielki. Puszka z 2 polowy XVII wieku (fot. E. Madejski, 1979). 
które wyszło z jego kancelarii z datą 5 maja 1786 r., zezwalało naszym eremitom prowadzić (z pewnymi ograniczeniami) owe bractwa. W roku następnym wyrazil również swoją aprobatę w tej sprawie sam prymas Michał Poniatowski.

Bractwo św. Anny tylko jeden raz pojawiło się w rękopisach konwentu, co miało miejsce w sierpniu 1756 r. Najpóźniej założone zostało przy klasztorze bractwo św. Tekli. Papież Klemens XIV w dniu 24 sierpnia 1772 r. nadał przywilej braciom pustelnikom w Książu Wielkim na założenie bractwa pod wezwaniem św. Tekli. Zawieral on wytyczne co do jego zorganizowania i odbywania praktyk religijnych. Sufragan krakowski Franciszek Potkański mianował dzień św. Tekli świętem bractwa, a oprócz tego wyznaczył cztery niedziele w roku na urządzanie uroczystości poświęconych temu stowarzyszeniu. Bractwo to powstało w Książu w r. 1779 i dla jego celów wystawiono ołtarz św. Tekli w kościele klasztornym. Przeglądając listy członków spostrzegamy tam nazwiska okolicznej szlachty, mieszczan i chłopów. Uczestniczący w nabożeństwie członkowie przywdziewali na siebie kapy brackie. Używano również tych kap przy kweście po domach lub w dni targowe po rynku czy na ulicach.

\section{WYKAZ ŹRÓDEŁ}

1. Archiwalia:

Archiwum Główne Akt Dawnych w Warszawie: dział VI-Kartografia 17 - 20a nr $181-1$ arkusz 12 .

Archiwum Kurii Metropolitalnej w Krakowie: Acta episcopalia, Acta officialia, Acta administratorialia.

Wojewódzkie Archiwum Państwowe w Krakowie, ul. Sienna 16: zespół „Augustianie"; Wawel-Zamek: Terrestria Cracoviensia, Castrensia Cracoviensia.

Wojewódzkie Archiwum Państwowe w Kielcach: Akta komisji województwa krakowskiego, nr 3493, 3494.

Kościół parafialny w Książu Wielkim: Akta metrykalne 1703 - 1863 r. Archiwalia poklasztorne.

Kazimierz Jan Kanty Dziuliński, Jan Michał Maruchowicz, Diariusz z lat 1693 - 1723 (E. Madejski nie wskazał miejsca przechowywania tego rękopisu).

Kronika parafialna z czasów proboszcza Grzegorza Augustynika (rękopis spalony około 1939 r.; tekstu odpisanego przez E. Madejskiego brak).

Regestra (!) fabryki przy kościele Księży Augustianów w Książu Wielkim 1836 - 1841 (kopia oryginału wykonana przez E. Madejskiego). 


\section{Druki:}

M. B a liński, T. Li pińs ki, Starożytna Polska, t. 2, Warszawa 1885.

L. Bi eń k ow ski, Zakony męskie w Polsce w 1772 r., Lublin 1972.

J. Dłu gosz, Liber beneficiorum dioecesis Cracoviensis, t. 1-3, Cracoviae $1863-1864$.

W. Dw or zaczek, Genealogia, Warszawa 1959 (tablice).

W. Dworzaczek, Leliwici Tarnowscy, Warszawa 1971.

A. Ka mińs ski, Zniszczenia wojenne $w$ Matopolsce $i$ ich skutki $w$ okresie najazdu szwedzkiego, [w:] Polska w okresie drugiej wojny pótnocnej 1655 1660 , t. 2, Warszawa 1957, s. $162 \mathrm{nn}$.

Kodeks dyplomatyczny małopolski, wyd. F. Pi k o osińs ki, t. 1-3, Kraków $1876-1886$.

P. Kubicki, Bojownicy kaptani za sprawę Kościoła $i$ Ojczyzny w latach $1861-1915$, t. 1, Sandomierz 1933.

W. Łuszczkiewicz, Kościót św. Katarzyny z klasztorem OO. Augustianów, Kraków 1898.

E. Madejski, Pałac Myszkowskich w Ksiqżu Wielkim, „Ochrona Zabytków" 1959 z. 1 s. $38-51$.

S. Pie k a rski, Prawdy i herezje, Warszawa 1930.

F. Pi e k os ińs ki, Rycerstwo polskie wieków średnich, t. 3, Kraków 1901.

M. Si p y $ł \nmid$ o, Akta synodów różnowierczych, t. 1, Warszawa 1966.

Starodawne prawa polskiego pomniki, wyd. B. Ulanowski, t. 8, Kraków 1884.

G. U th, Szkic historyczno-biograficzny zakonu augustianów w Polsce, Kraków 1930.

\section{LE COUVENT DES AUGUSTINS À KSIĄŻ WIELKI (1372 - 1894)}

\section{Résumé}

L'édification du couvent remonte à 1372, époque où Jean de Melsztyn grand seigneur, châtelain de Cracovie et héritier de Książ Wielki fit venir dans ces lieux les eremites de Saint Augustin. Il fit construire une église en la dédiant au Saint Esprit et en la dotant de tout L'améagement necessaire aux offices. En 1381, son fils Spytek, en tant qu'héritier, accepte la succession paternelle en tant que telle,et l'agrandit, en faisant bâtir un couvent pour les moines.

La Réforme ébranle cette situation établie et réglementée. Lorsque Książ Wielki tomba entre les mains de Jean Boner, nouveau propriétaire et, de surcroît, calviniste reconnu, le glas sonna pour le clergé seculier et régulier qui fut obligé de partir. Les Augustins ne purent revenir à Książ Wielki qu'après le rachat de ces biens par l'évêque de Cracovie Pierre Myszkowski. Alors ils recon- 
struisirent leur couvent. Le XVII ${ }^{\mathrm{e}}$ siècle fut une époque d'intense développement grace aux riches dans de nombreux bienfaiteurs.

Au XVIII ${ }^{\mathrm{e}}$ siècle, pendant „la guerre du nord” le couvent subit de nombreuses et graves destructions. A nouveau, de nombreux bienfaiteurs participèrent à sa reconstruction après les ravages causés par cette affreuse guerre. En 1741, un incendie le dévaste. Un autre, en 1836, réduit en cendres les trois quarts des monuments précieux qui l'ornaient. A nouveau, il fut réédifié mais cette fois-ci, il perdit ses traits architectoniques d'origine.

Ainsi, au XIX ${ }^{\mathrm{e}}$ siècle, l'église du Saint Esprit gothique à l'origine, fut flanquée d'une façade classique. Le Choeur et la sacristie fort anncienne uniquement conservèrent un caractère gothique. Quant à la nef centrale, elle porte les marques de la fin du baroque. L'autel principal avec un tabernacle baroque ainsi qu'une peinture représentant la Vierge Marie, oeuvre de G. B. Salvi-Sassoferrato, artiste italien du XVII ${ }^{\mathrm{e}}$ siècle, invité par le père provincial Adeodate Buczkiewicz, retiennent notre attention. Egalement, dans le presbytère, il y a de très intéressants tableaux représentants Sainte Catherine et Saint André. La chaire de couleur blanche aux rebords dorés avec un toit baldaquin orné d'une sculpture baroque représentant Saint Augustin éclate de beauté. Dans la nef centrale de l'église, s'élèvent quatre autels avec des peintures représentant Saint Nicolas, Sainte Tecla, Saint André et celui avec une sculpture du Jesus Christ „Ecce Homo”. Ces quatre autels portent l'empreinte du style classique.

La longue liste des prieurs du couvent à Książ Wielki commence par frère Etienne, noté dans les archives du début du XVe siècle. Le dernier des prieurs qui a rempli cette fonction jusqu'en 1864 fut Luc Wacław Morawski. En 1864, le couvent n'existant plus ses biens furent confisqués. La cause directe de sa liquidation fut la resurrection de janvier. Après la cassation de la convention il y reste un seul moine, le prêtre François Śliwiński. Ce fut le dernier représentant du couvent de Saint Augustin à Książ Wielki. Avec sa mort, en 1815 prend fin le séjour des Augustins dans ses lieux. 